Wildlife Program

Prepared in cooperation with the San Diego Association of Governments (SANDAG), U.S. Fish and Wildlife Service (USFWS), California Department of Fish and Wildlife (CDFW), Bureau of Land Management (BLM), and San Diego Management and Monitoring Program (SDMMP)

\title{
Biotelemetry Data for Golden Eagles (Aquila chrysaetos) Captured in Coastal Southern California, February 2017- December 2019
}

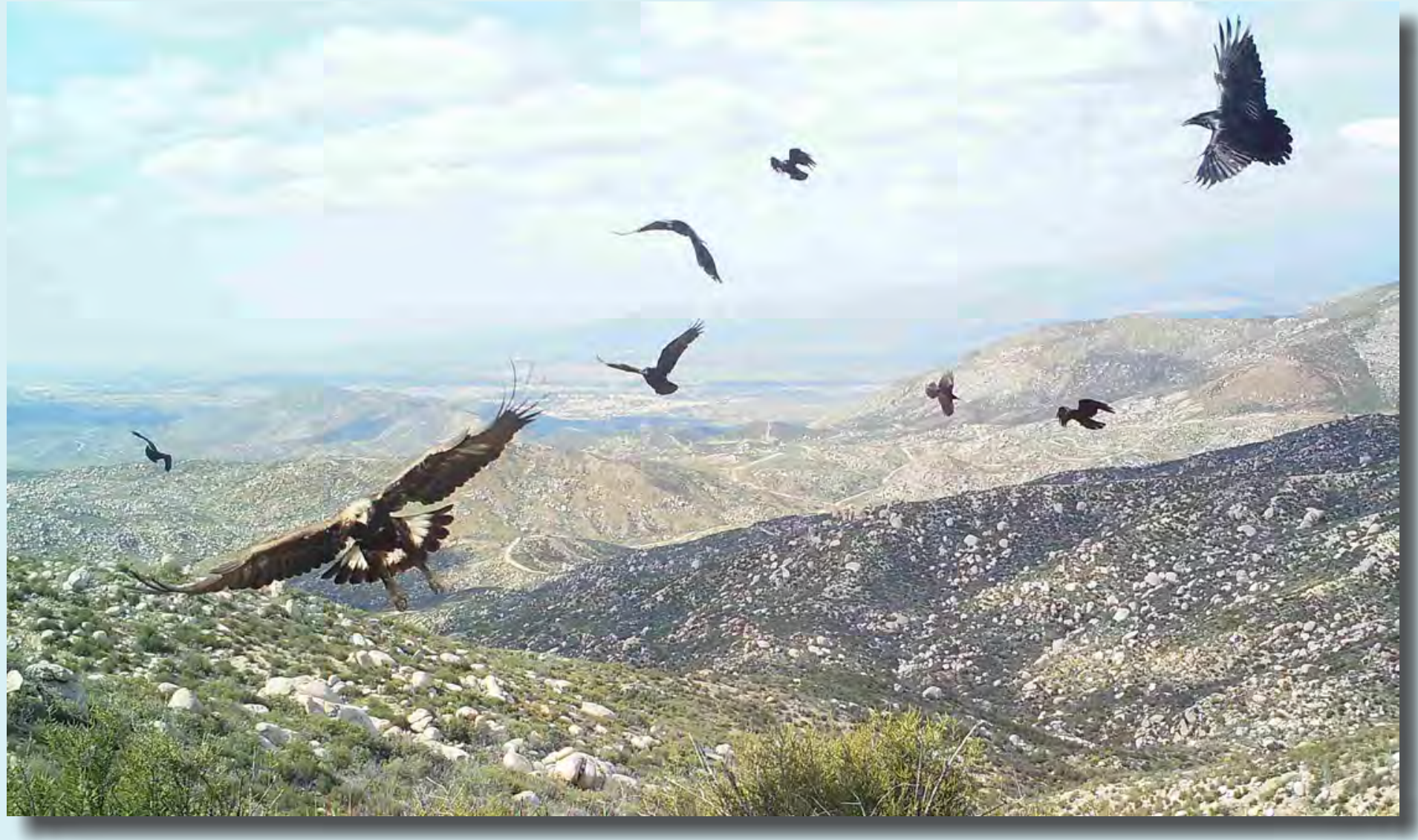

Data Series 1128 
Cover Photo: Photograph of a golden eagle approaching a bait station followed by common ravens, March 23, 2018. Photograph taken by a motion-triggered wildlife camera. 


\section{Biotelemetry Data for Golden Eagles (Aquila chrysaetos) Captured in Coastal Southern California, February 2017- December 2019}

By Jeff A. Tracey, Melanie C. Madden, James C. Molden, Jeremy B. Sebes, Peter H. Bloom, and Robert N. Fisher

Wildlife Program

Prepared in cooperation with the San Diego Association of Governments (SANDAG), U.S. Fish and Wildlife Service (USFWS), California Department of Fish and Wildlife (CDFW), Bureau of Land Management (BLM), and San Diego Management and Monitoring Program (SDMMP)

Data Series 1128 


\title{
U.S. Department of the Interior \\ DAVID BERNHARDT, Secretary
}

\author{
U.S. Geological Survey \\ James F. Reilly II, Director
}

U.S. Geological Survey, Reston, Virginia: 2020

For more information on the USGS - the Federal source for science about the Earth, its natural and living resources, natural hazards, and the environment—visit https://www.usgs.gov or call 1-888-ASK-USGS.

For an overview of USGS information products, including maps, imagery, and publications, visit https://store.usgs.gov/.

Any use of trade, firm, or product names is for descriptive purposes only and does not imply endorsement by the U.S. Government.

Although this information product, for the most part, is in the public domain, it also may contain copyrighted materials as noted in the text. Permission to reproduce copyrighted items must be secured from the copyright owner.

Suggested citation:

Tracey, J.A., Madden, M.C., Molden, J.C., Sebes, J.B., Bloom, P.H., and Fisher, R.N., 2020, Biotelemetry data for Golden Eagles (Aquila chrysaetos) captured in coastal southern California, February 2017-December 2019: U.S. Geological Survey Data Series 1128, 34 p., https://doi.org/10.3133/ds1128.

ISSN 2327-638X (online) 


\section{Acknowledgments}

We thank the U.S. Geological Survey field biologists who have made this project possible, including Jordyn Mulder, Monique Wong, Michelle Curtis, Devin Adsit-Morris, Karen Aerni, Nicole Deatherage, Robert Krijgsman, Cary Cochran, Omar Guerra Salcido, Tristan Edgarian, and Wendy Bear. We thank Sue Phillips, Susan Jones (U.S. Geological Survey, retired), Diane Elam, and Keith Miles of the U.S. Geological Survey for their managerial support.

We would also thank Bloom Biological Inc. biologists Kerry Ross, Galen Reid, Michael Kuehn, Marcus England, Karly Moore, and Jackie Catino, and Breanna Bartels, and Wendy Humphrey, and Nicollet Overby of Bloom Biological Inc. for administrative support. John Martin, Jeff Wells, Joe Papp, Sharon Coe, Kris Preston, Barbara Kus, Suellen Lynn, Marla Steele, and Dustin Janeke volunteered to assist in eagle trapping.

Members of the numerous agencies provided support, including the California Department of Fish and Wildlife (Karen Miner, Tracie Nelson, Jason Price, Carie Battistone, and Rich Burg, Eddy Kono, Scott Sewell, Randy Botta, Nicholas Peterson, and Hans Sin); the U.S. Fish and Wildlife Service (Susan Wynn, Mary Beth Woulfe, Tom Dietsch, Jill Terp, John Martin, Randy Nagel, Joel Pagel, and Karen Goebel); the Bureau of Land Management (Amy Fesnock, Joyce Schlachter, James Gannon, Thomas Zale, and Carrie Sahagun), the U.S. Forest Service (Jeff Wells), the County of San Diego (Jennifer Price, Mary Niez, Margaret Diss, Ranger Walt Schmidtke, Ranger Kyle Icke, and Ranger Roger Covalt), the City of San Diego (Nicole McGinnis, Brent Peterson, John Barone, and Tim Nguyen), San Diego Assocication of Governments/San Diego Monitoring and Management Program (Keith Greer, Paul Fromer, Ron Rempel, Yvonne Moore, Kris Preston, Emily Perkins, and the Environmental Mitigation Program Working Group), the Irvine Ranch Conservancy (David Raetz, Sherry Fuller, and Jutta Burger), Orange County Parks (John Gump and Sean Bengtson), California State Parks (Ken Kietzer and Michael Puzzo, and Gina Moran), Pala Band of Mission Indians, Corte Madera Ranch, Jerry Crowe FBI Regional Tactical Training Center (El Toro), Santa Margarita Ecological Reserve (Pablo Bryant), Back Country Land Trust, Santa Rosa Plateau Ecological Reserve (Carole Bell), Diego Medina and Gonzalo De León (Centro de Investigaciones Biológicas del Noroeste, S.C.), and Amber Craig (Border Patrol), and John and Kim Smiley. We thank Winston Vickers (University of California, Davis) and Jeff Lincer (Researchers Implementing Conservation Action) for their support. We thank Michael Lanzone, Andrew McGann, Sheldon Blackshire, Bob Fogg, and Jeannine Parvin at Cellular Tracking Technologies for technical support. Finally, Frank Konyn, Robert Van Ommering, Brad Scott, and Steve Stiles provided assistance in acquiring bait. 



\section{Contents}

Acknowledgments ……...................................................................................................................

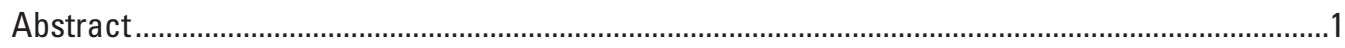

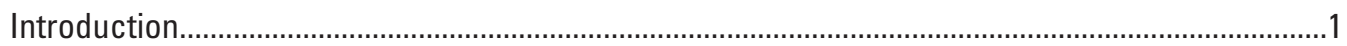

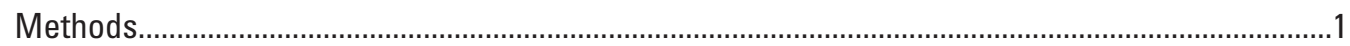

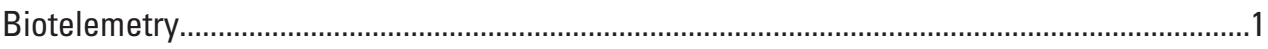

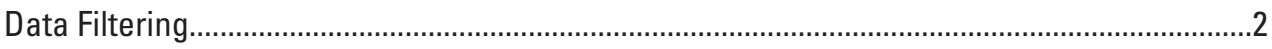

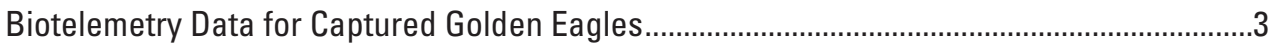

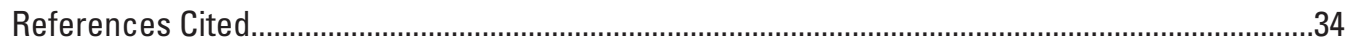

\section{Figures}

1. Map showing Golden eagles trapping locations in southern California,

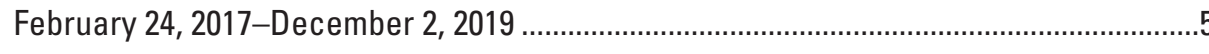

2. Map showing movement data for all eagles tracked, February 24, 2017-

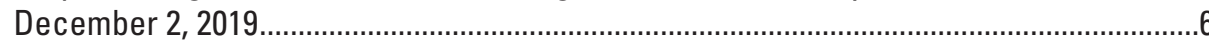

3. Map showing location data for eagle GOEA-SD-F001 captured at Boulder Oaks, San Diego County, California, November 22, 2014........................................................

4. Map showing location data for eagle GOEA-SD-F002 recaptured at Pamo Valley, San Diego County, California, March 6, 2018.......................................................8

5. Map showing location data for eagle GOEA-SD-F007 captured at Long Potrero, San Diego County, California, February 23, 2015 ............................................................

6. Map showing location data for eagle GOEA-RV-F010 captured at Santa Rosa Plateau, Riverside County, California, December 12, 2015...........................................10

7. Map showing location data for eagle GOEA-SD-F011 captured at Proctor Valley, San Diego County, California, December 20, 2015........................................................11

8. Map showing location data for eagle GOEA-OC-F012 captured at Fremont Canyon, Orange County, California, December 10, 2016

9. Map showing location data for eagle GOEA-SD-F013 captured at Boucher Hill, San Diego County, California, February 11, 2016

10. Map showing location data for eagle GOEA-OC-F014 captured at Fremont Canyon, Orange County, California, February 12, 2016.

11. Map showing location data for eagle GOEA-OC-F015 captured at Fremont Canyon, Orange County, California, February 12, 2016.

12. Map showing location data for eagle GOEA-SD-F016 captured at Barrett Lake, San Diego County, California, March 5, 2016

13. Map showing location data for eagle GOEA-SD-F017 captured at Little Tecate, San Diego County, California, November 4, 2016.

14. Map showing location data for eagle GOEA-SD-F019 captured at Pamo Valley, San Diego County, California, January 14, 2017

15. Map showing location data for eagle GOEA-SD-F020 captured at Gregory Mountain, San Diego County, California, January 21, 2017

16. Map showing location data for eagle GOEA-SD-F021 captured at Pamo Valley, San Diego County, California, January 29, 2017...

17. Map showing location data for eagle GOEA-SD-F022 captured at Oak Grove, San Diego County, California, January 30, 2017. 
18. Map showing location data for eagle GOEA-SD-F026 captured at Pamo Valley, San Diego County, California, February 9, 2018.

19. Map showing location data for eagle GOEA-SD-F027 captured at Pamo Valley, San Diego County, California, February 21, 2018

20. Map showing location data for eagle GOEA-SD-F028 captured at Pamo Valley, San Diego County, California, March 18, 2018

21. Map showing location data for eagle GOEA-SD-M001 captured at Cedar Canyon, San Diego County, California, December 5, 2014

22. Map showing location data for eagle GOEA-SD-M003 captured at Rancho Cañada, San Diego County, California, February 3, 2015.

23. Map showing location data for eagle GOEA-SD-M005 captured at Long Potrero, San Diego County, California, February 23, 2015 ...

24. Map showing location data for eagle G0EA-SD-M007 captured at Long Valley, San Diego County, California, December 9, 2015.....

25. Map showing location data for eagle GOEA-SD-M013 captured at Boucher Hill, San Diego County, California, November 20, 2016.

26. Map showing location data for eagle GOEA-SD-M015 captured at Table Mountain, San Diego County, California, January 28, 2017.

27. Map showing location data for eagle GOEA-SD-M019 captured at Gregory Mountain, San Diego County, California, January 30, 2018. 31

28. Map showing location data for eagle GOEA-SD-M020 captured at Pamo Valley, San Diego County, California, January 31, 2018.

29. Map showing location data for eagle GOEA-SD-M021 captured at McCain Valley, San Diego County, California, February 23, 2018.

\section{Tables}

1. Summary of golden eagles tracked in southern California, February $24,2017-$ December 2, 2019.. 


\section{Conversion Factors}

International System of Units to U.S. customary units

\begin{tabular}{lcl}
\multicolumn{1}{c}{ Multiply } & By & \multicolumn{1}{c}{ To obtain } \\
\hline & Length & \\
\hline millimeter $(\mathrm{mm})$ & 0.03937 & inch \\
kilometer $(\mathrm{km})$ & 0.6214 & mile $(\mathrm{mi})$ \\
\hline \multicolumn{3}{c}{ Flow rate } \\
\hline meter per second $(\mathrm{m} / \mathrm{s})$ & 3.281 & foot per second $(\mathrm{ft} / \mathrm{s})$ \\
\hline \multicolumn{3}{c}{ Mass } \\
\hline gram $(\mathrm{g})$ & 0.03527 & ounce, avoirdupois $(\mathrm{oz})$ \\
\hline
\end{tabular}

\section{Datum}

Vertical coordinate information is referenced to the World Geodetic System 1984 (WGS 84).

Horizontal coordinate information is referenced to the World Geodetic System 1984 (WGS 84).

Altitude, as used in this report, refers to distance above the vertical datum.

\section{Supplemental Information}

Concentrations of lead in blood are given in micrograms per deciliter ( $\mu \mathrm{g} / \mathrm{dL}) .1 \mu \mathrm{g} / \mathrm{dL}$ is the equivalent of 0.001 parts per million (ppm). 



\title{
Biotelemetry Data for Golden Eagles (Aquila chrysaetos) Captured in Coastal Southern California, February 2017- December 2019
}

\author{
By Jeff A. Tracey1, Melanie C. Madden1, James C. Molden1, Jeremy B. Sebes', Peter H. Bloom², and \\ Robert N. Fisher ${ }^{1}$
}

\section{Abstract}

Because of a lack of clarity about the status of golden eagles (Aquila chrysaetos) in coastal southern California, the U.S. Geological Survey, in collaboration with U.S. Fish and Wildlife Service, California Department of Fish and Wildlife, Bureau of Land Management, and San Diego Management and Monitoring Program, began a multi-year survey and tracking program of golden eagles to address questions regarding habitat use, movement behavior, nest occupancy, genetic population structure, and human impacts on eagles. Golden eagle trapping and tracking efforts began in September 2014. During trapping efforts from September 29, 2014, to February 23, 2017, 37 golden eagles were captured. During trapping efforts from February 24, 2017, to December 2, 2019, an additional 7 golden eagles (4 females and 3 males) were captured, and one previously captured female was recaptured in San Diego County. Biotelemetry data for 27 of the 44 golden eagles that were transmitting data from February 24, 2017, to December 2, 2019, are presented. These eagles ranged as far north as British Columbia, Canada, and as far south as Ciudad Insurgentes, Baja California, Mexico.

\section{Introduction}

Growing uncertainty about the status of golden eagles (Aquila chrysaetos) in southern California has highlighted the need for ecological information that will allow local managers to evaluate and mitigate the effects of human activities on this species (Scott, 1985; Harlow and Bloom, 1989). Depending on the season, the population of golden eagles in California typically is comprised of adult territorial breeders, adult floaters, locally fledged juvenile and subadults, nomadic birds of all ages, as well as migrants with origins from more northerly or southerly latitudes. A better understanding

1U.S. Geological Survey.

2Bloom Biological, Inc. of the current distribution, status, foraging requirements, and population characteristics of golden eagles can help to manage golden eagle habitat and threats/stressors to each nesting territory in coastal southern California. Recent work has been completed in the Mojave Desert and the Tehachapi Mountains in southern California (Braham and others, 2015; Poessel and others, 2016), but there is no previous work from the coastal areas or the Sonoran Desert. The U.S. Geological Survey (USGS) in collaboration with U.S. Fish and Wildlife Service (USFWS), California Department of Fish and Wildlife (CDFW), Bureau of Land Management (BLM), and San Diego Management and Monitoring Program (SDMMP) began a multi-year survey and tracking program of golden eagles to address questions regarding habitat use, movement behavior, nest occupancy, genetic population structure, and human impacts on eagles. This report presents golden eagle capture and biotelemetry data from February 24, 2017, through December 2, 2019. Capture and biotelemetry data for November 22, 2014, to February 23, 2017, are available in Tracey and others $(2016,2017)$.

\section{Methods}

\section{Biotelemetry}

Eagles were captured by using a remotely triggered bow net trap baited with a carcass. Once captured, each eagle was given an eagle identification (ID) for this study, a USGS Bird Banding Laboratory leg band (if it did not already have one), and a Global Positioning System (GPS) transmitter that sends data over the mobile phone network (a GPS-GSM transmitter; Lanzone and others, 2012). The eagle ID consists of a four-letter code for the species, a two-letter code for the county of capture, and an "F" or "M" followed by a numeral (with up to two leading zeros) to indicate the sex and capture order of the individual. For example, the first female eagle captured in San Diego County was given an eagle ID of GOEA-SD-F001. We use the county code OC for Orange County and RV for Riverside County. 
Standard morphological measurements and samples were taken from each captured eagle. Measurements included (1) weight, (2) hallux and culmen, and (3) characteristics of the primary and secondary flight feathers. Samples included (1) blood samples for genetic and lead testing; (2) swabs of the eyes, mouth, and cloaca for chlamydia testing by the University of California, Davis; and (3) two to four feathers for lead, stable isotope, and genetic testing. For the health of the eagle, rapid processing and release took precedence over collecting measurements and samples. Thus, in some cases we did not collect weight measurements or take blood samples for field lead testing in favor of properly attaching the GPS-GSM unit and releasing the eagle in a timely manner. When time and the ambient temperatures permitted, eagles were tested in the field for lead toxicity using a LeadCare ${ }^{\circledR}$ II testing unit. If lead testing results were greater than 60 micrograms per deciliter $(\mu \mathrm{g} / \mathrm{dL})$, we planned to deliver the eagle to Scott Weldy DVM (Orange County Bird of Prey Center, Serrano Animal \& Bird Hospital) for therapy. All samples were collected under Dr. Peter Bloom's scientific collecting permit (Bloom Biological, Inc.) and delivered to the appropriate parties (University of California, Davis Wildlife Health Center, Todd Katzner of USGS, and Andrew DeWoody of Purdue University—each of whom is permitted to receive samples). No samples were retained in California by the USGS. Any request for results of analysis of these samples should be directed to the individual or organization to whom the samples were delivered. Sex was determined based on body size, weight, and measurements of the hallux and culmen and will be confirmed genetically. Age was estimated based on molt patterns (Bloom and Clark, 2001).

Each captured eagle was fitted with a Cellular Tracking Technologies (CTT'TM) CTT ${ }^{\mathrm{TM}}$-1070a or CTT ${ }^{\mathrm{TM}}-1000$-BT3 GPS-GSM telemetry unit (Lanzone and others, 2012). The about 72-gram units (about 1-2 percent of an eagle's total weight) were attached to the eagles using 11 millimeter ( $\mathrm{mm}$ ) natural tubular Teflon TM tape fed through the attachment holes on the GSP-GSM unit and around the wings to form a "backpack" (Dunstan, 1972; Kenward, 1985). The Teflon ${ }^{\mathrm{TM}}$ ribbon is non-abrasive and is the standard method for attaching telemetry units to eagles. If the eagle had other markings or telemetry devices, in addition to a USGS Bird Banding Laboratory (BBL) leg band, we were directed by the $\mathrm{BBL}$ to remove them.

\section{Data Filtering}

Once data were downloaded from CTT ${ }^{\mathrm{TM}}$ servers, the data were formatted (for example, formatting dates and converting text strings with latitude and longitude data into numerical values). We applied two filters to the records to eliminate potentially erroneous locations.

To pass the first filter, six conditions had to be satisfied:

1. Location had to be a 3D fix,

2. Horizontal dilution of precision (HDOP) had to be less than or equal to 5 ,

3. Vertical dilution of precision (VDOP), if available, had to be less than or equal to 5 ,

4. Longitude values had to be available and be on the interval $[-180,-100]$ degrees,

5. Latitude values had to be available and be on the interval $[20,72]$ degrees, and

6. Fixes had to be at least 2 seconds apart (based on discussion with engineers at CTTTM taking new flight mode firmware into account).

The second filter depends on move step (in other words, a displacement between two consecutive observed locations) distance metrics. To pass the second filter, three conditions had to be satisfied:

1. The start and end location must have passed the first filter (above),

2. Location had to be within UTM zones 10,11 , or 12 and both the start and end location had to be in the same UTM zone (because the UTM coordinates were used to calculate the move distances for step three that follows), and

3. Rate of displacement had to be realistic (less than or equal to 89.4 meters per second $[\mathrm{m} / \mathrm{s}]$ horizontal or less than or equal to $20.0 \mathrm{~m} / \mathrm{s}$ vertical).

After filtering on move step distances, any location that was not the beginning or end point of a move step was removed because it was associated only with a move step that had unrealistic rates of movement. 


\section{Biotelemetry Data for Captured Golden Eagles}

From September 29, 2014, to December 2, 2019, we baited at 168 different locations in San Diego, Orange, and western Riverside Counties of southern California and captured a total of 44 golden eagles. During this reporting period, February 24, 2017-December 2, 2019, we baited at 30 locations, captured 7 new and recaptured 1 golden eagle for a total of 8 golden eagles at 4 trapping locations, and collected biotelemetry data from a total of 27 golden eagles, including 20 that were captured prior to February 24, 2017 (table 1; fig. 1). For the 20 eagles captured prior to February 24, 2017, see Tracey and others $(2016,2017)$ for a map of the bait sites at which they were captured. Of the eagles for which telemetry data were collected during the reporting period, there were 8 eagles with operational transmitters, 2 eagles with transmitters of unknown status, 11 eagles with non-functional transmitters, 3 eagles known to have removed their transmitters (based on telemetry data and recovery of the transmitter) and 3 eagles known to have died (see "Status" column, table 1). An operational transmitter is one from which we have received data within the past 10 days. A transmitter with unknown status is one from which we have received data from 11 to 60 days prior, a non-functional transmitter is one from which we have not received data in more than 60 days, and a fatality indicates that we have recovered the eagle's remains. Several eagles with non-functional transmitters have been observed alive in the field. Fifteen of the eagles appeared to have had breeding territories, seven appeared to have been adult floaters (that is, adults without a breeding territory), four were nomadic subadults (that is, wandering eagles typically too young to hold a breeding territory), and one had undetermined territorial behavior (see "Behavior" column, table 1). For territorial adults, the place name of the territory is given in the "Territory Name" column. No telemetry data were collected during this reporting period for 17 golden eagles (8 confirmed fatalities and 11 apparent transmitter failures) that were included in Tracey and others $(2016,2017)$.

A view of the location data over the entire extent of the area used by the golden eagles is shown in figure 2. Note that a lack of eagle data for a particular area does not necessarily imply that it is not used by eagles. We are only tracking a subset of the population of eagles in southern California, so empty areas still could be utilized by eagles that we are not tracking. Location data for 27 captured golden eagles with transmitters that produced telemetry data during the reporting period are shown in figures 3-29. The San Diego Association of Governments (SANDAG) funded the telemetry data collection for this report and the data will be housed with the SDMMP. 
Table 1. Summary of golden eagles tracked in southern California, February 24, 2017-December 2, 2019.

[Bait site ID: Locations of bait site IDs are shown in figure 1 of this report or in Tracey and others (2016, 2017; fig. 1). Abbreviations: ID, identification; mm-dd-yyy hh:mm, month-day-year hour:minute; no., number; Sex: F, female; M, male; Age: HY, hatch year; TY, third year; FY, fourth year; AFY, after fourth year; AFFY, after fifth year]

\begin{tabular}{|c|c|c|c|c|c|c|c|c|c|}
\hline Eagle ID & $\begin{array}{c}\text { Date/time } \\
\text { (mm-dd-yyyy hh:mm) }\end{array}$ & Location & $\begin{array}{l}\text { Bait site } \\
\text { ID }\end{array}$ & $\begin{array}{l}\text { Figure no. for } \\
\text { location data }\end{array}$ & Sex & $\begin{array}{l}\text { Age at time } \\
\text { of capture }\end{array}$ & Status ${ }^{1}$ & Behavior2 & Territory name \\
\hline GOEA-SD-F001 & 11-22-2014 17:00 & Boulder Oaks & IRON03 & 3 & $\mathrm{~F}$ & AFY & Operational & Territory-holder & Iron Mountain \\
\hline${ }^{3}$ GOEA-SD-F002 & 03-06-2018 08:00 & Pamo Valley & PAMO05 & 4 & $\mathrm{~F}$ & AFFY & Operational & Adult Floater & \\
\hline GOEA-SD-F007 & 02-23-2015 17:00 & Long Potrero & LOPO01 & 5 & $\mathrm{~F}$ & AFFY & Removed & Territory-holder & Tecate \\
\hline GOEA-RV-F010 & $12-12-2015$ 09:20 & Santa Rosa Plateau & SRPT01 & 6 & $\mathrm{~F}$ & AFY & Non-functional & Territory-holder & Los Alamos \\
\hline GOEA-SD-F011 & $12-20-2015$ 11:23 & Proctor Valley & RJER07 & 7 & $\mathrm{~F}$ & TY & Non-functional & Nomadic Subadult & \\
\hline GOEA-OC-F012 & 02-10-2016 17:00 & Fremont Canyon & FRMT03 & 8 & $\mathrm{~F}$ & AFFY & Non-functional & Adult Floater & \\
\hline GOEA-SD-F013 & 02-11-2016 17:00 & Boucher Hill & PALA09 & 9 & $\mathrm{~F}$ & AFFY & Removed & Territory-holder & Boucher Hill \\
\hline GOEA-OC-F014 & 02-12-2016 17:00 & Fremont Canyon & FRMT03 & 10 & $\mathrm{~F}$ & AFFY & Fatality & Adult Floater & \\
\hline GOEA-OC-F015 & 02-12-2016 17:00 & Fremont Canyon & FRMT03 & 11 & $\mathrm{~F}$ & AFFY & Fatality & Territory-holder & Fremont Canyon \\
\hline GOEA-SD-F016 & 03-05-2016 12:00 & Barrett Lake & BARR04 & 12 & $\mathrm{~F}$ & AFFY & Removed & Territory-holder & Barrett/Echo Mountain \\
\hline GOEA-SD-F017 & 11-04-2016 11:30 & Little Tecate & OTAY18 & 13 & $\mathrm{~F}$ & AFY & Operational & Territory-holder & Marron Valley \\
\hline GOEA-SD-F019 & 01-14-2017 06:55 & Pamo Valley & PAMO05 & 14 & $\mathrm{~F}$ & FY & Unknown & Nomadic Subadult & \\
\hline GOEA-SD-F020 & 01-21-2017 15:00 & Gregory Mountain & PALA11 & 15 & $\mathrm{~F}$ & AFFY & Non-functional & Adult Floater & \\
\hline GOEA-SD-F021 & 01-29-2017 09:30 & Pamo Valley & PAMO05 & 16 & $\mathrm{~F}$ & SY & Non-functional & Nomadic Subadult & \\
\hline GOEA-SD-F022 & 01-30-2017 08:00 & Oak Grove & OGVA05 & 17 & $\mathrm{~F}$ & AFFY & Operational & Territory-holder & Oak Grove \\
\hline GOEA-SD-F026 & 02-09-2018 06:30 & Pamo Valley & PAMO09 & 18 & $\mathrm{~F}$ & SY & Non-functional & Nomadic Subadult & \\
\hline GOEA-SD-F027 & 02-21-2018 07:30 & Pamo Valley & PAMO09 & 19 & $\mathrm{~F}$ & SY & Operational & Nomadic Subadult & \\
\hline GOEA-SD-F028 & 03-18-2018 09:00 & Pamo Valley & PAMO09 & 20 & $\mathrm{~F}$ & FY & Unknown & Nomadic Subadult & \\
\hline GOEA-SD-M001 & $12-05-2014$ 17:00 & Cedar Canyon & OTAY01 & 21 & M & AFY & Operational & Territory-holder & Cedar Canyon \\
\hline GOEA-SD-M003 & 02-03-2015 17:00 & Rancho Canada & IRON05 & 22 & M & AFFY & Non-functional & Territory-holder & Iron Mountain \\
\hline GOEA-SD-M005 & 02-23-2015 17:00 & Long Potrero & LOPO01 & 23 & M & AFFY & Non-functional & Territory-holder & Barrett/Echo Mountain \\
\hline GOEA-SD-M007 & 12-09-2015 10:15 & Long Valley & CORT04 & 24 & M & AFY & Non-functional & Territory-holder & $\begin{array}{l}\text { Lower Intake/San Luis } \\
\text { Rey River Gorge }\end{array}$ \\
\hline GOEA-SD-M013 & $11-20-2016$ 17:00 & Boucher Hill & PALA09 & 25 & M & AFY & Operational & Territory-holder & Boucher Hill \\
\hline GOEA-SD-M015 & 01-28-2017 15:30 & Table Mountain & TAMO04 & 26 & M & AFFY & Non-functional & Undetermined & \\
\hline GOEA-SD-M019 & 01-30-2018 11:00 & Gregory Mountain & PALA13 & 27 & M & AFFY & Fatality & Territory-holder & Gregory Mountain \\
\hline GOEA-SD-M020 & 01-31-2018 07:50 & Pamo Valley & PAMO09 & 28 & M & SY & Non-functional & Nomadic Subadult & \\
\hline GOEA-SD-M021 & 02-23-2018 10:00 & McCain Valley & MCCN09 & 29 & M & AFFY & Operational & Territory-holder & Carrizo Gorge \\
\hline
\end{tabular}

IIn Tracey and others $(2016,2017)$, "Operational" was referred to as "Active" and "Non-functional” was refered to as "Inactive."

2In Tracey and others (2016, 2017), we used the term "Floater" as a general term for nomadic eagles of all ages. Here we distinguish between nomadic subadults ("Nomadic Subadult") that typically are too young to hold a breeding territoy and nomadic adults ("Adult Floater") that may be actively searching for a breeding territory.

${ }^{3}$ Recaptured golden eagle. The original transmitter was malfunctioning, so she was fitted with a new transmitter. The original capture date was November 28, 2014, on Otay Mountain at the OTAY1 bait site. 


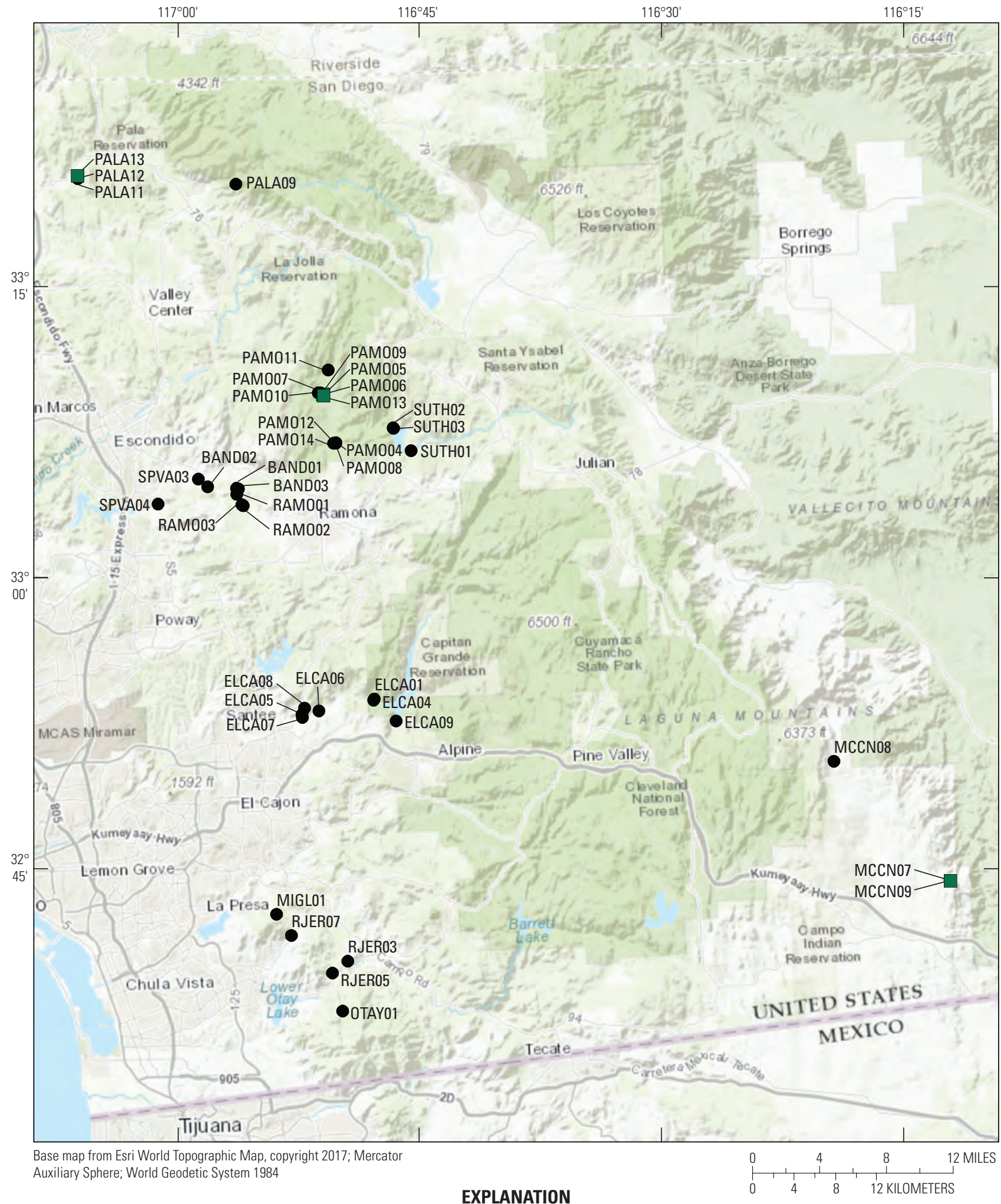

Bait site-Number is site id (table 1)

PAM005 One or more eagles captured

OTAY01 Eagle not captured

Figure 1. Golden eagles trapping locations in southern California, February 24, 2017-December 2, 2019. 


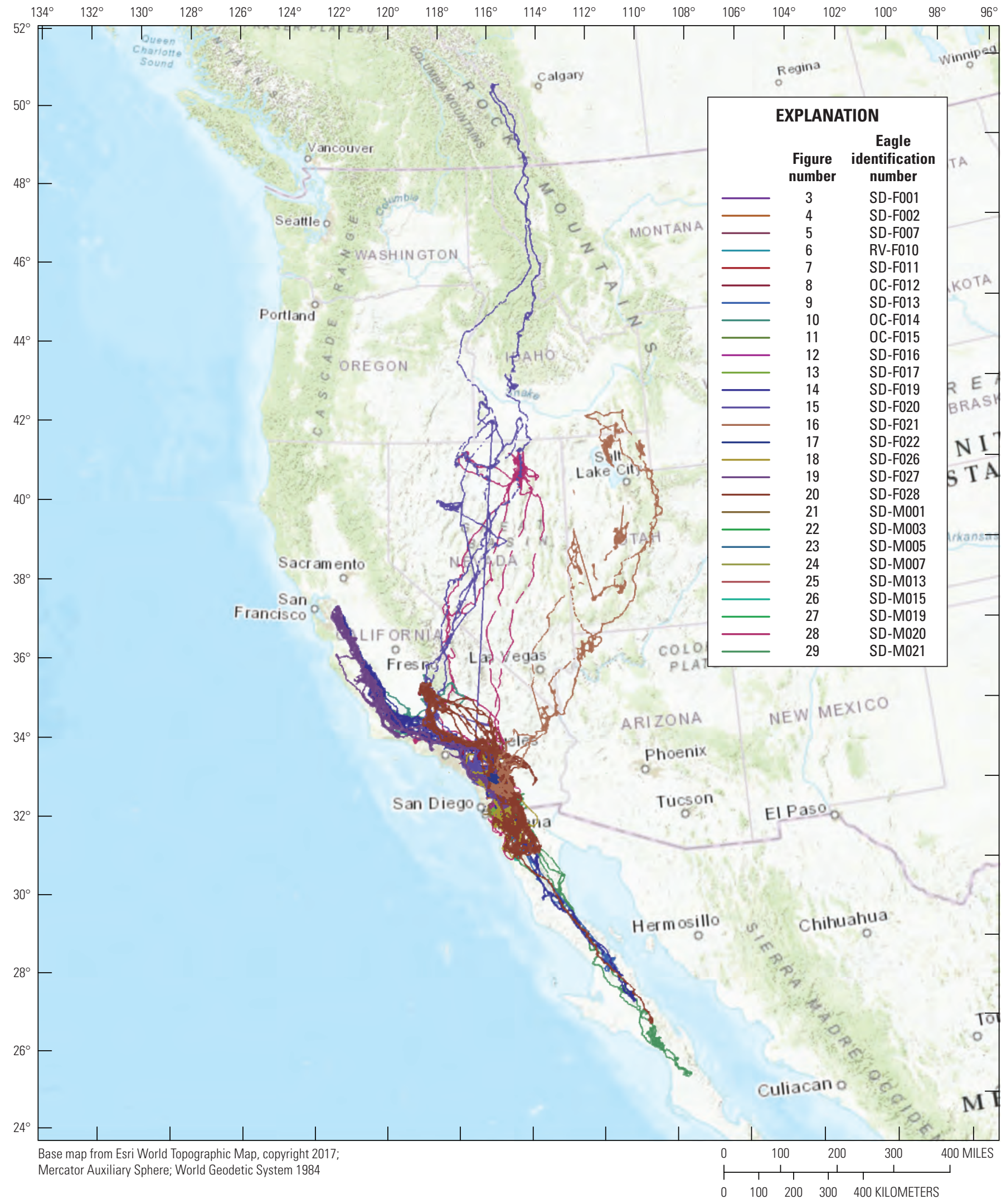

Figure 2. Movement data for all eagles tracked, February 24, 2017-December 2, 2019. 


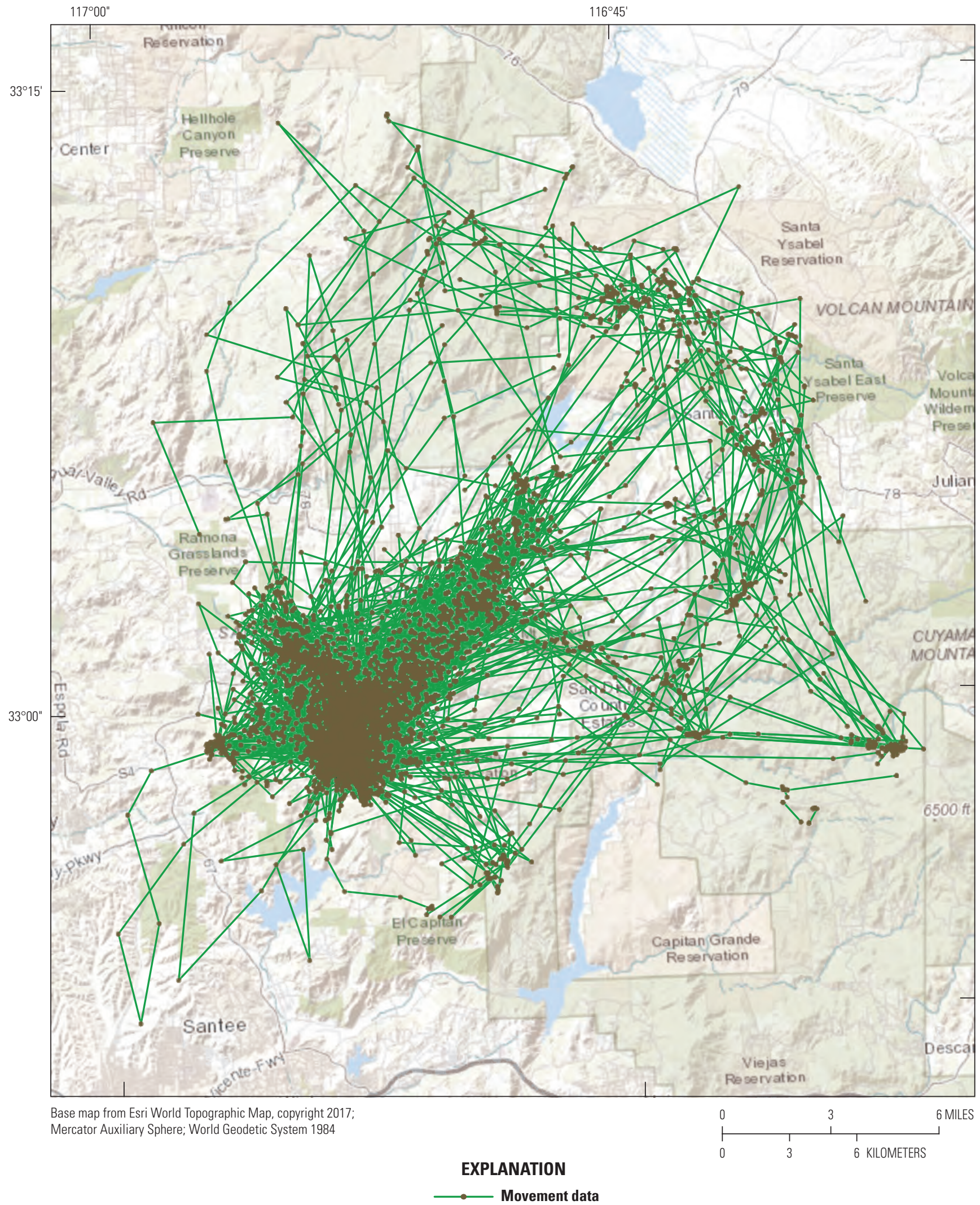

Figure 3. Location data for eagle GOEA-SD-F001 captured at Boulder Oaks, San Diego County, California, November 22, 2014. 


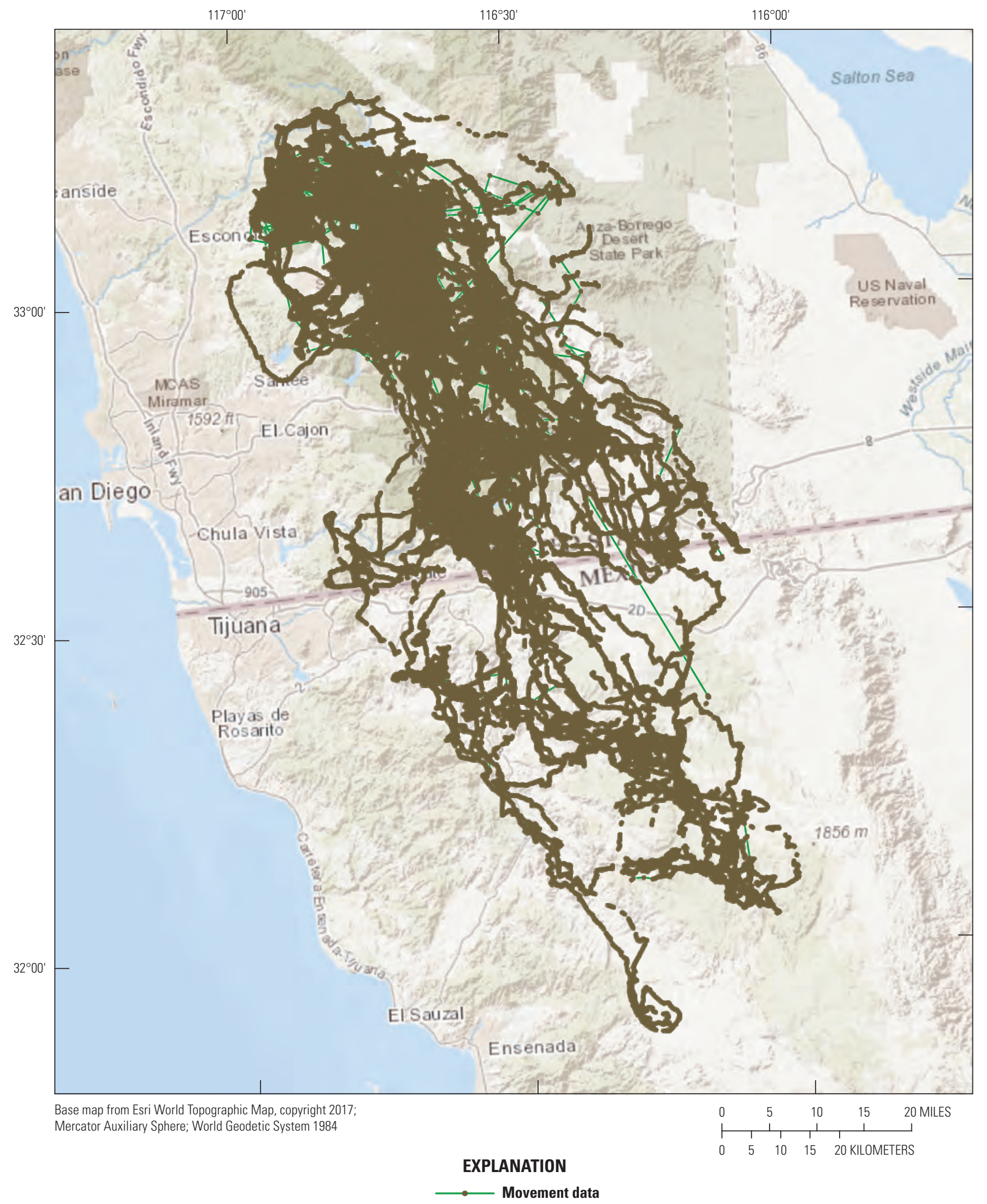

Figure 4. Location data for eagle GOEA-SD-F002 recaptured at Pamo Valley, San Diego County, California, March 6, 2018. 


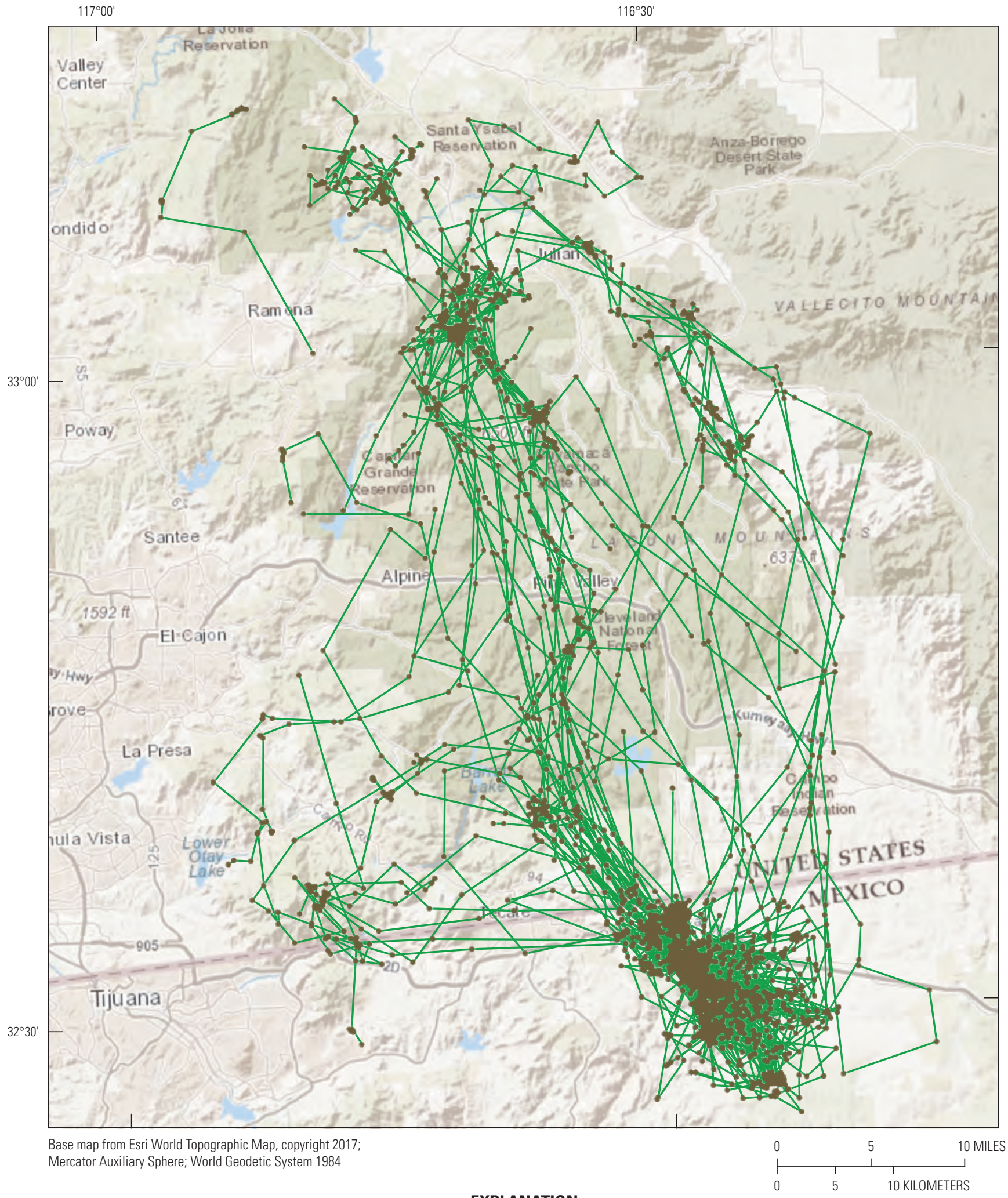

EXPLANATION

Figure 5. Location data for eagle GOEA-SD-F007 captured at Long Potrero, San Diego County, California, February $23,2015$. 


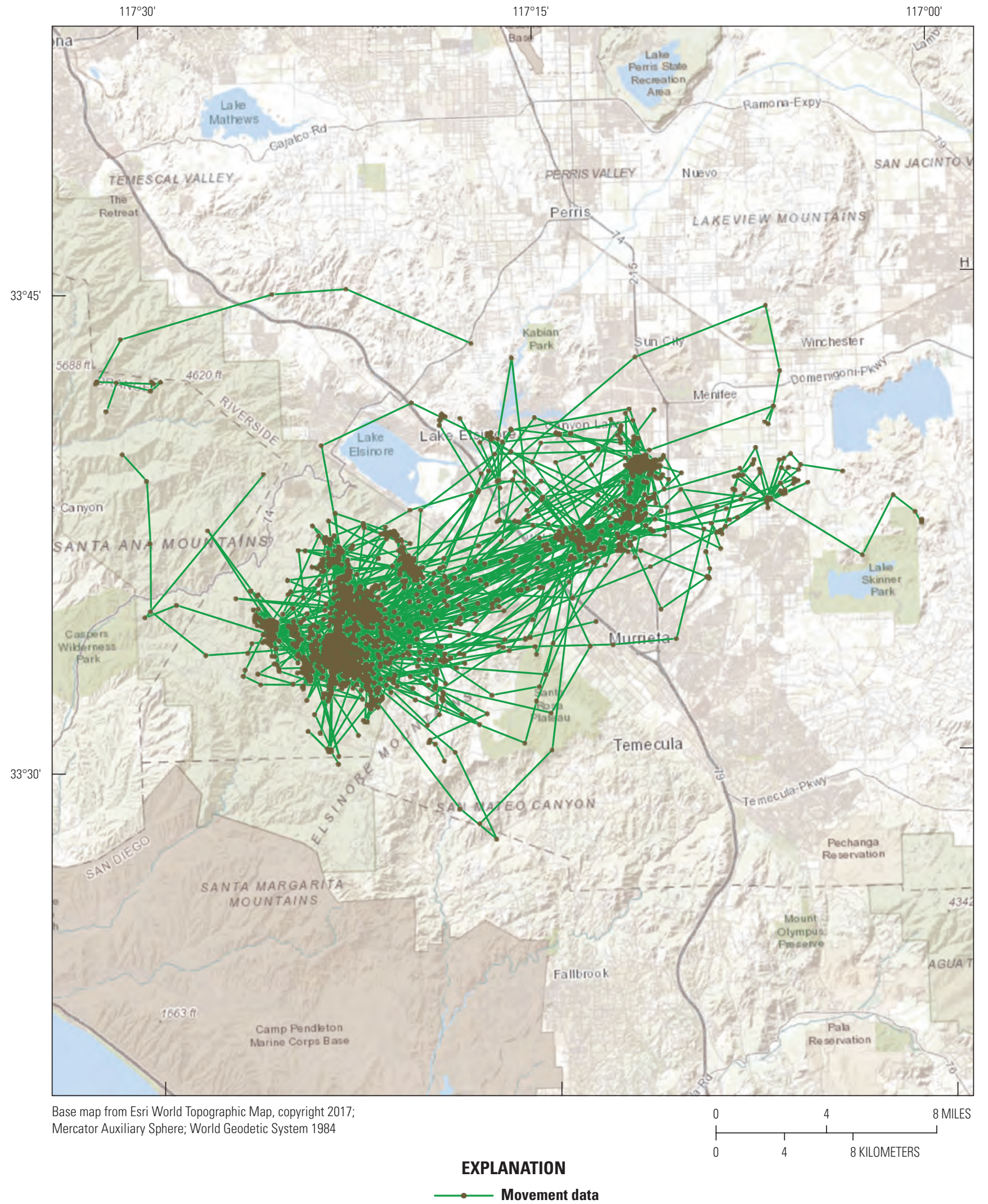

Figure 6. Location data for eagle GOEA-RV-F010 captured at Santa Rosa Plateau, Riverside County, California, December 12, 2015. 


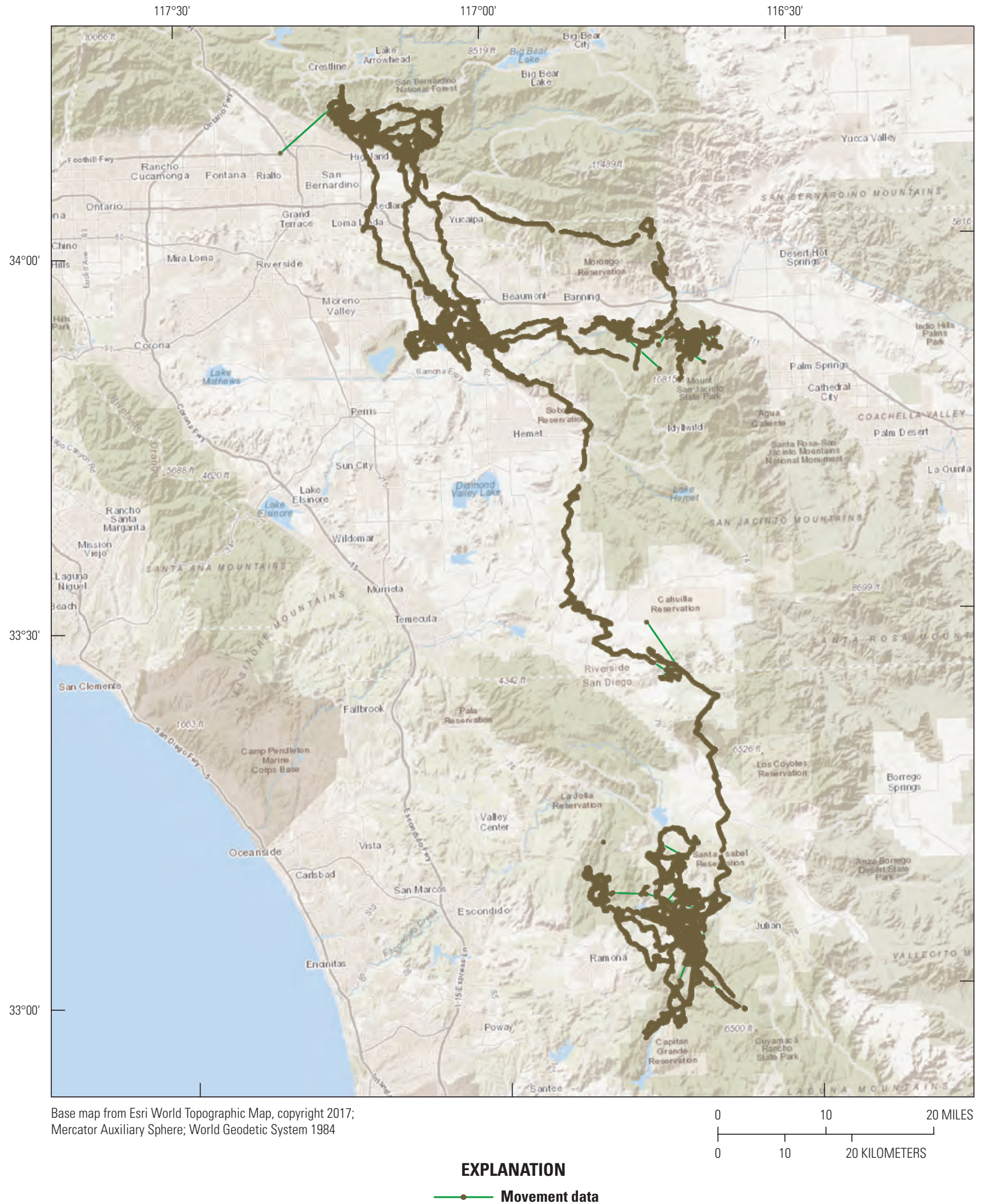

Figure 7. Location data for eagle GOEA-SD-F011 captured at Proctor Valley, San Diego County, California, December 20, 2015. 


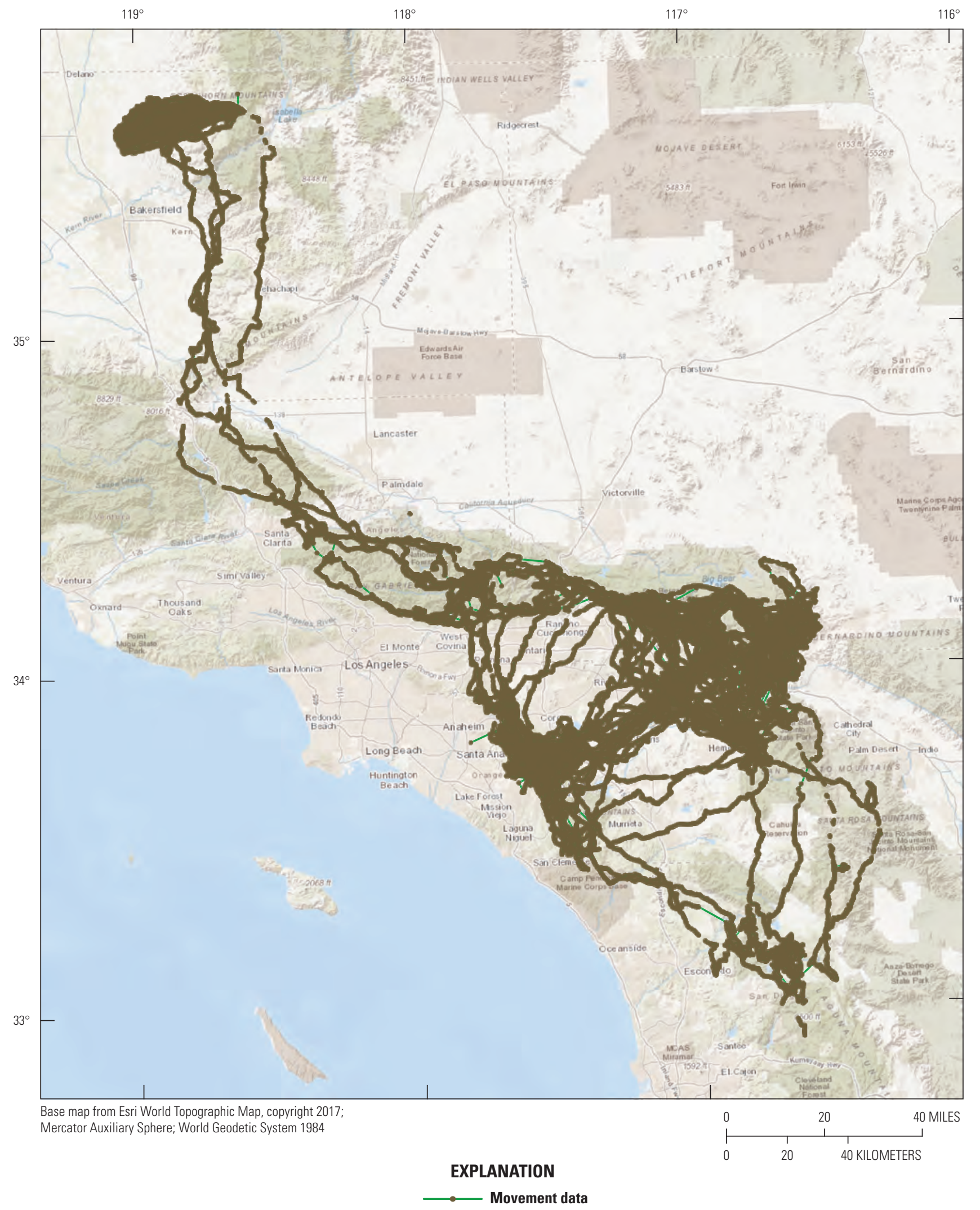

Figure 8. Location data for eagle GOEA-OC-F012 captured at Fremont Canyon, Orange County, California, December 10, 2016. 


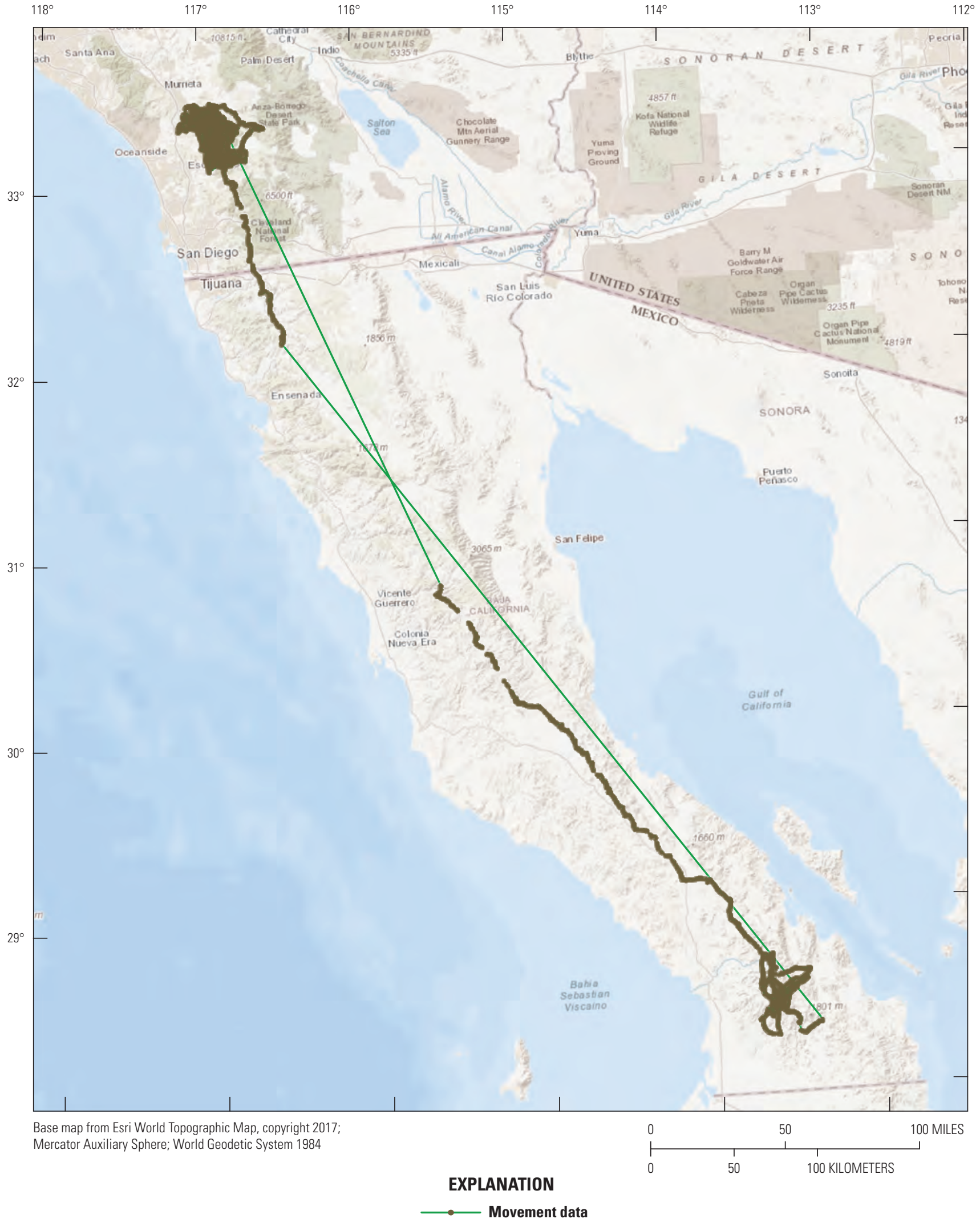

Figure 9. Location data for eagle GOEA-SD-F013 captured at Boucher Hill, San Diego County, California, February 11, 2016. 


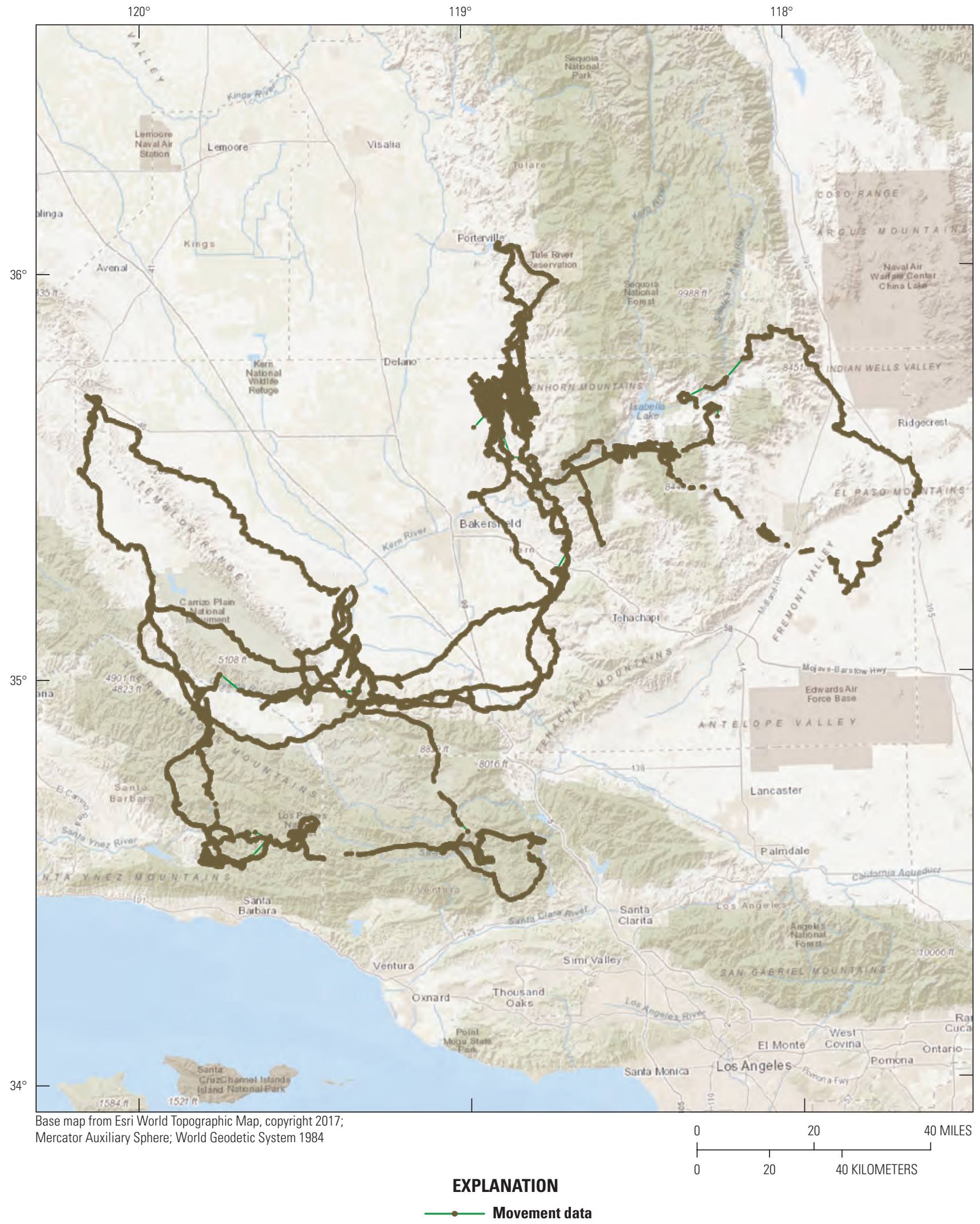

Figure 10. Location data for eagle GOEA-OC-F014 captured at Fremont Canyon, Orange County, California, February 12, 2016. 


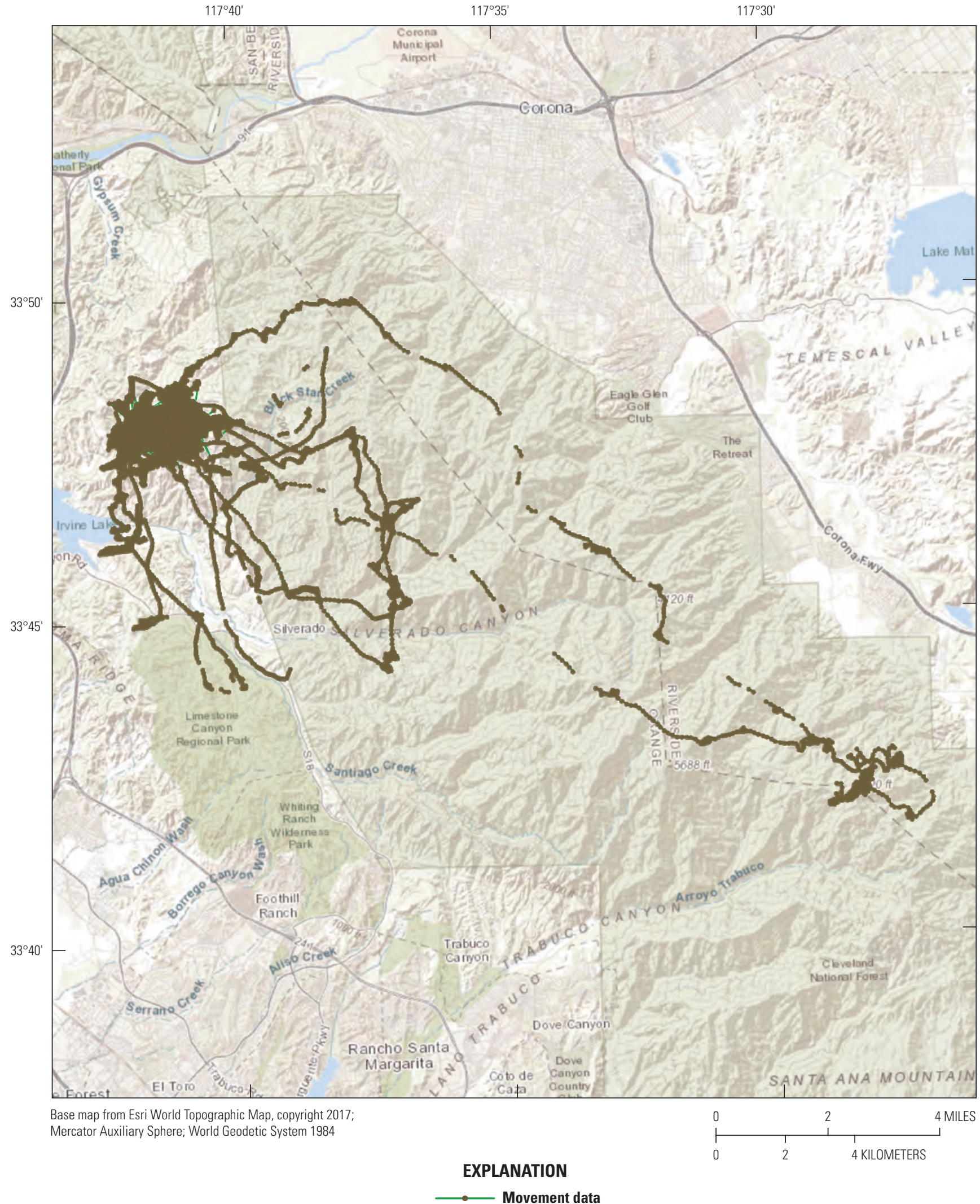

Figure 11. Location data for eagle GOEA-OC-F015 captured at Fremont Canyon, Orange County, California, February 12, 2016. 


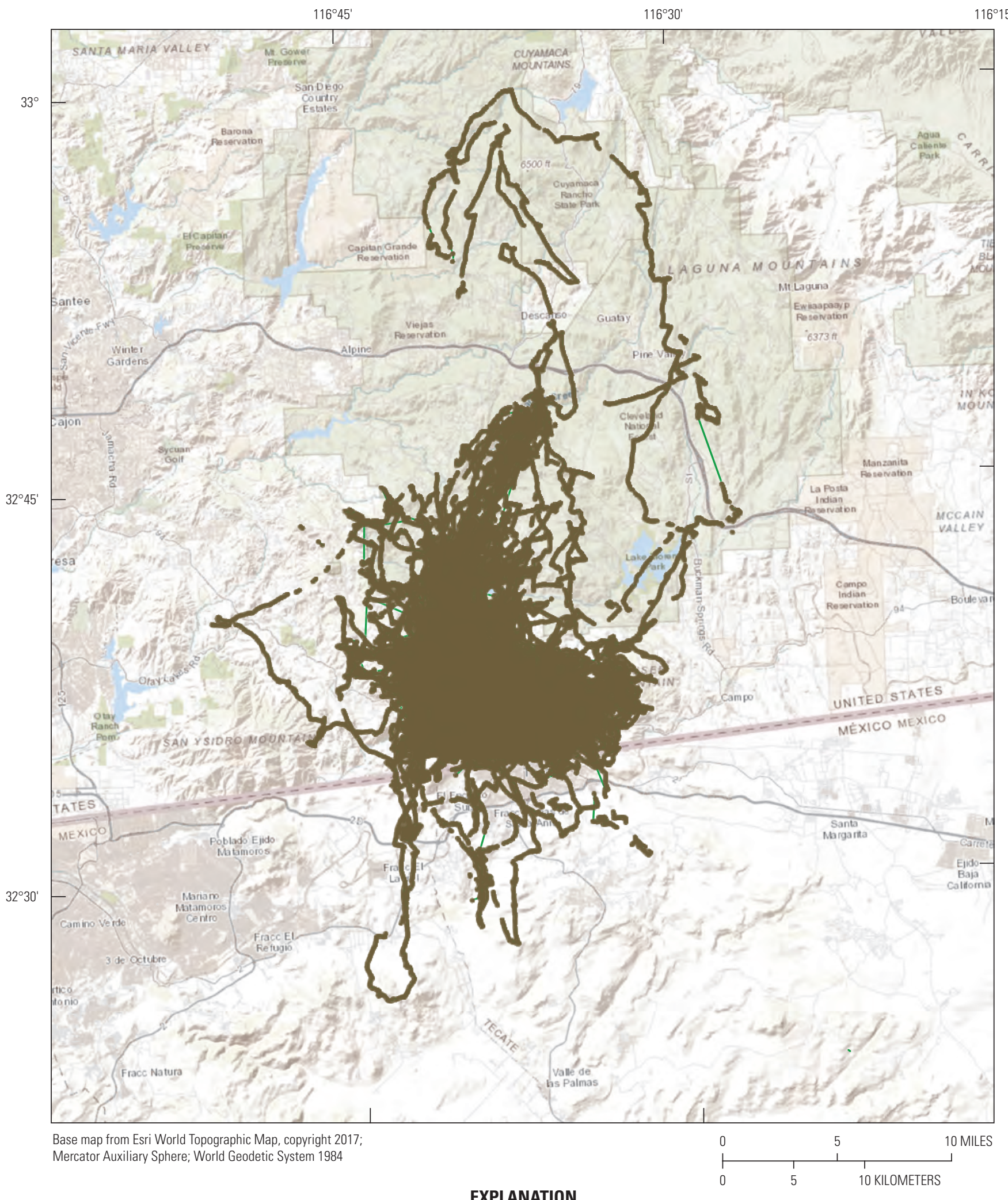

EXPLANATION

Figure 12. Location data for eagle GOEA-SD-F016 captured at Barrett Lake, San Diego County, California, March 5, 2016. 


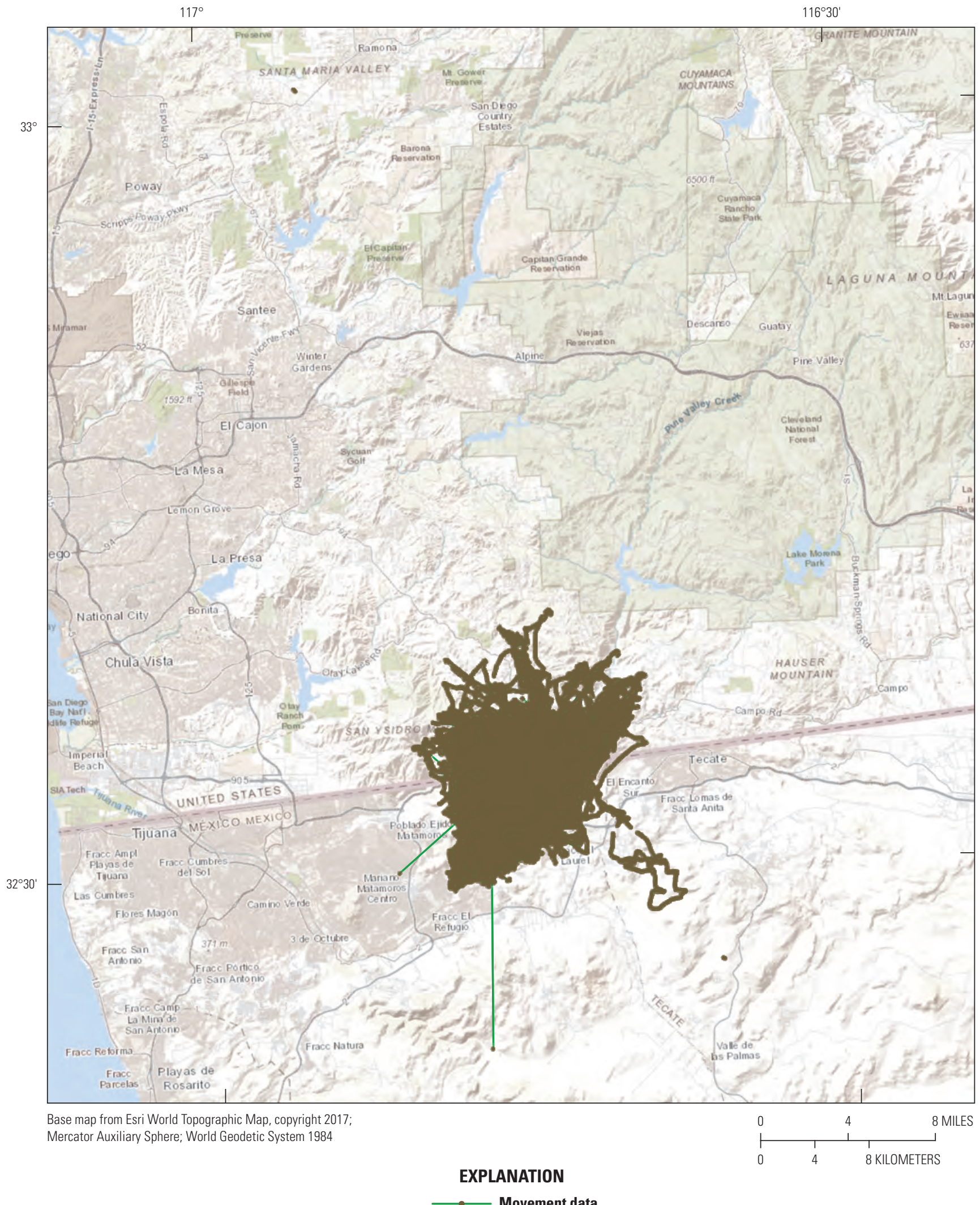

Figure 13. Location data for eagle GOEA-SD-F017 captured at Little Tecate, San Diego County, California, November 4, 2016. 


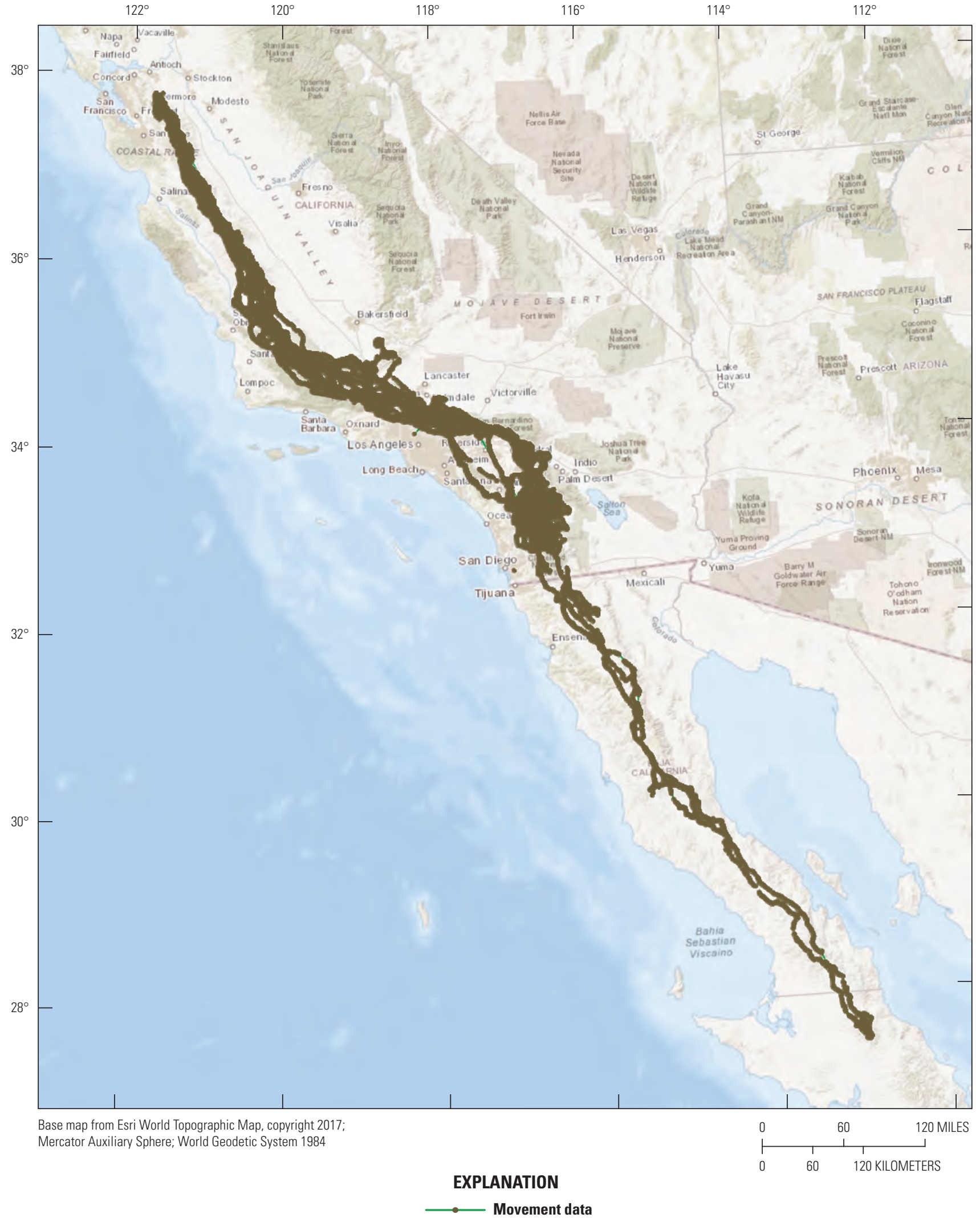

Figure 14. Location data for eagle GOEA-SD-F019 captured at Pamo Valley, San Diego County, California, January 14, 2017. 


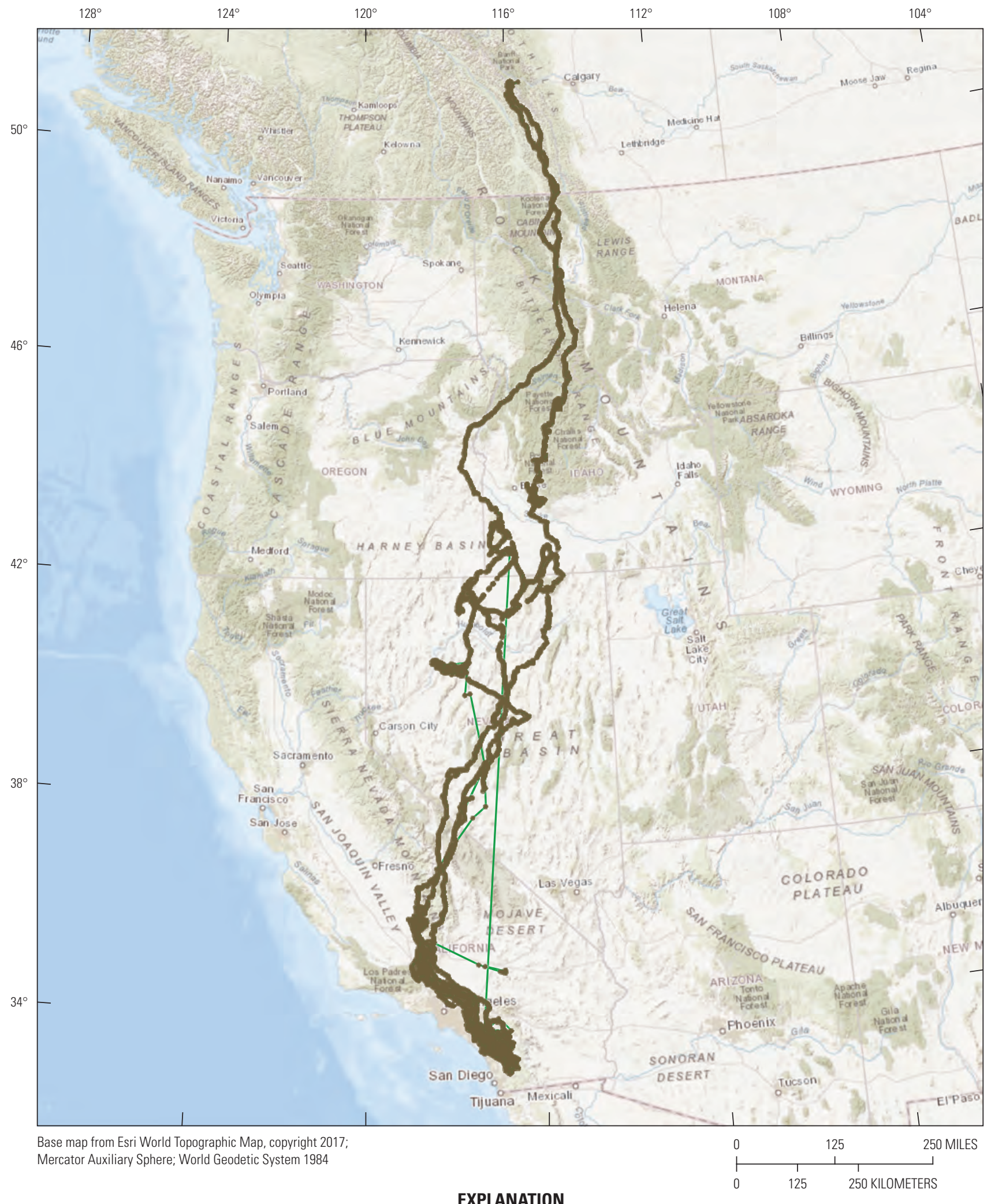

EXPLANATION

Movement data

Figure 15. Location data for eagle GOEA-SD-F020 captured at Gregory Mountain, San Diego County, California, January 21, 2017. 


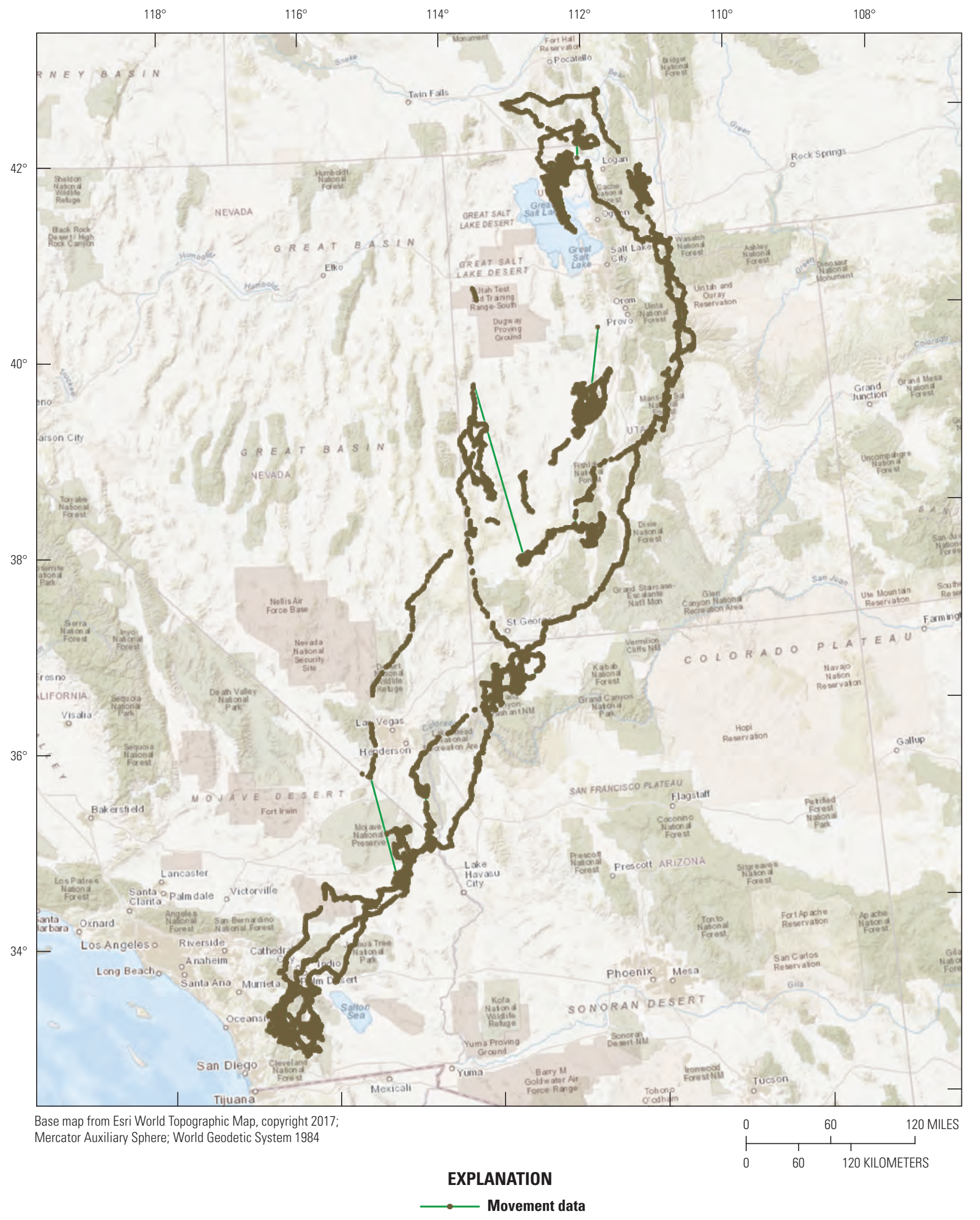

Figure 16. Location data for eagle GOEA-SD-F021 captured at Pamo Valley, San Diego County, California, January 29, 2017. 


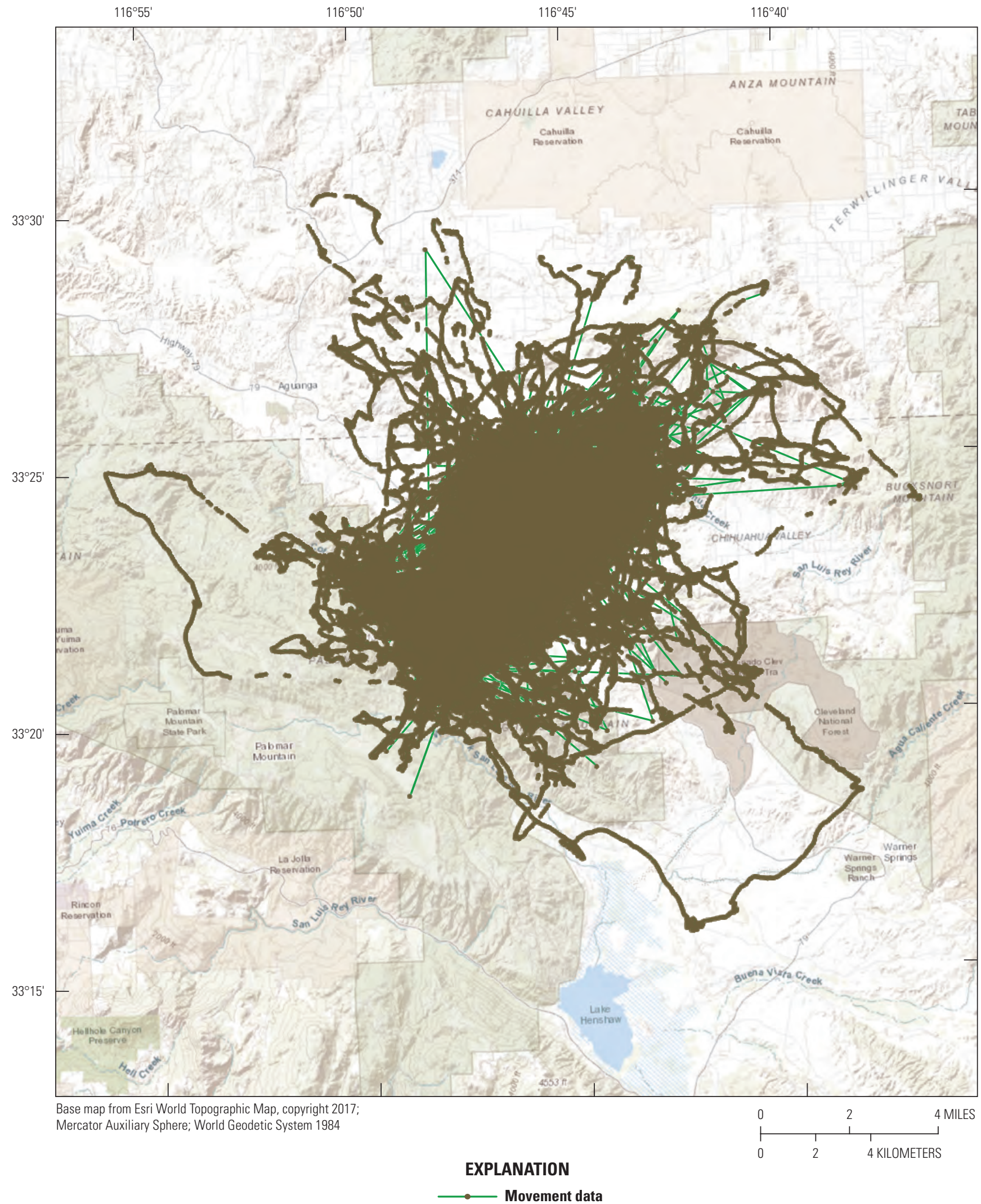

Figure 17. Location data for eagle GOEA-SD-F022 captured at Oak Grove, San Diego County, California, January 30, 2017. 


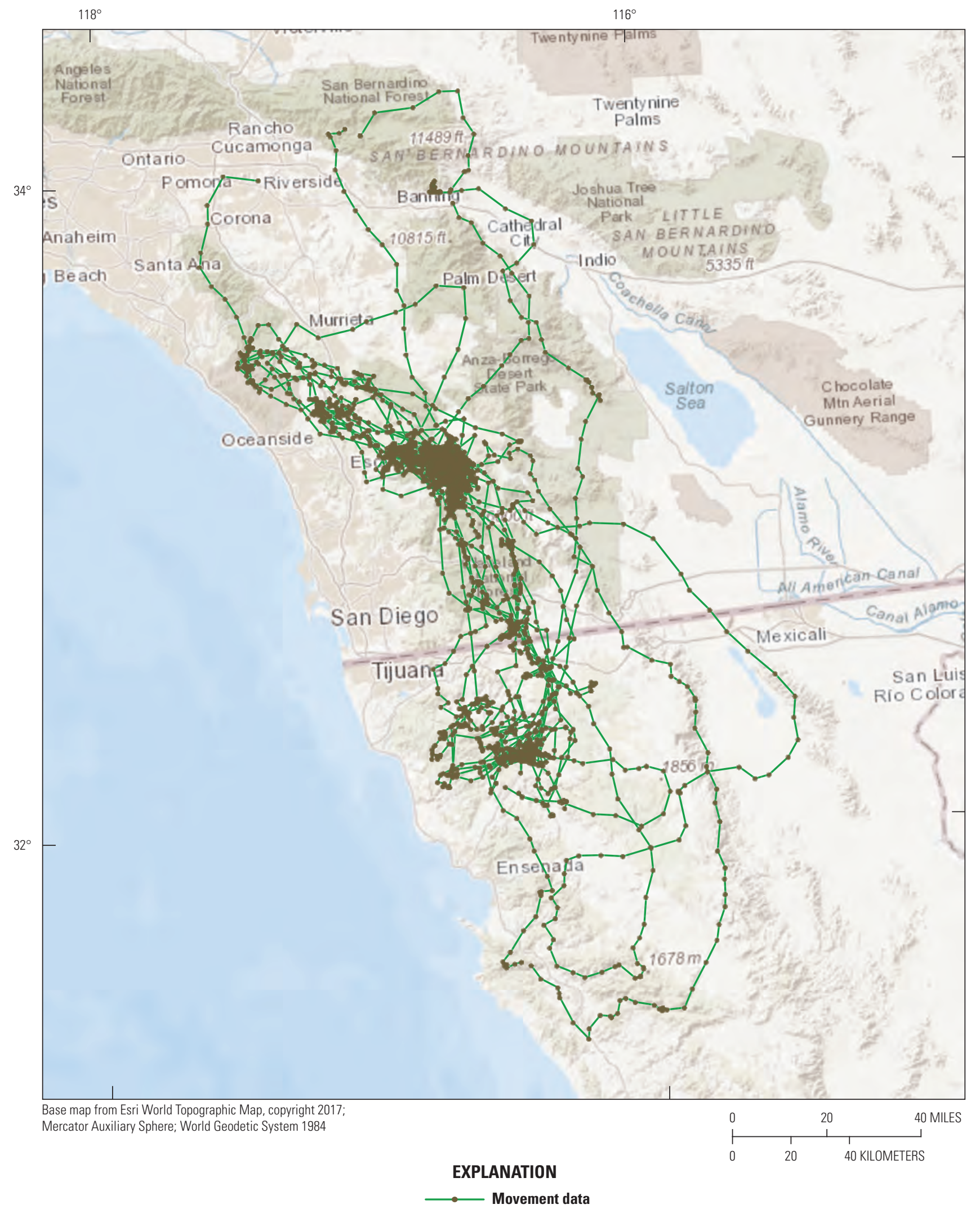

Figure 18. Location data for eagle GOEA-SD-F026 captured at Pamo Valley, San Diego County, California, February 9, 2018. 


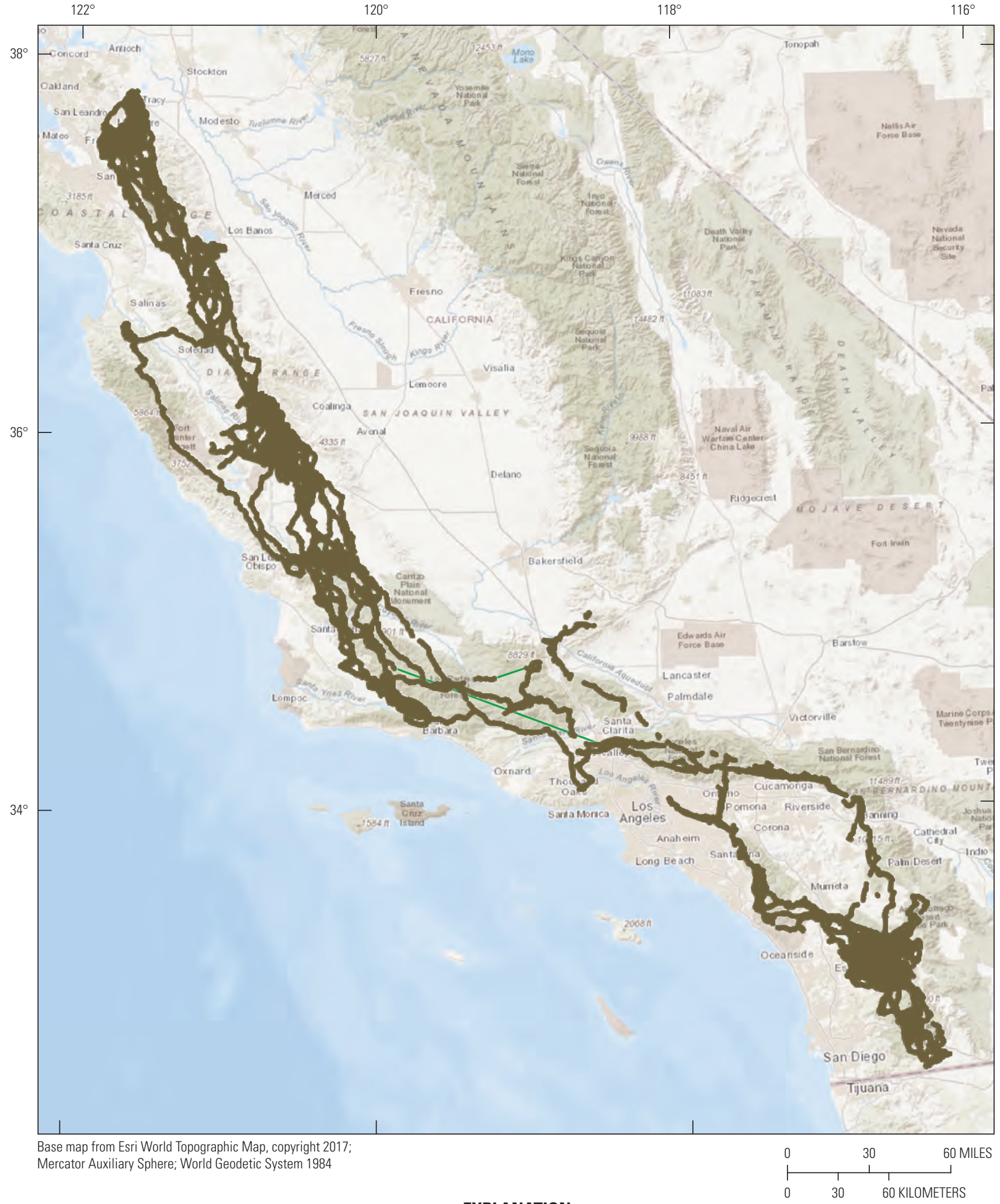

EXPLANATION

Movement data

Figure 19. Location data for eagle GOEA-SD-F027 captured at Pamo Valley, San Diego County, California, February 21, 2018. 


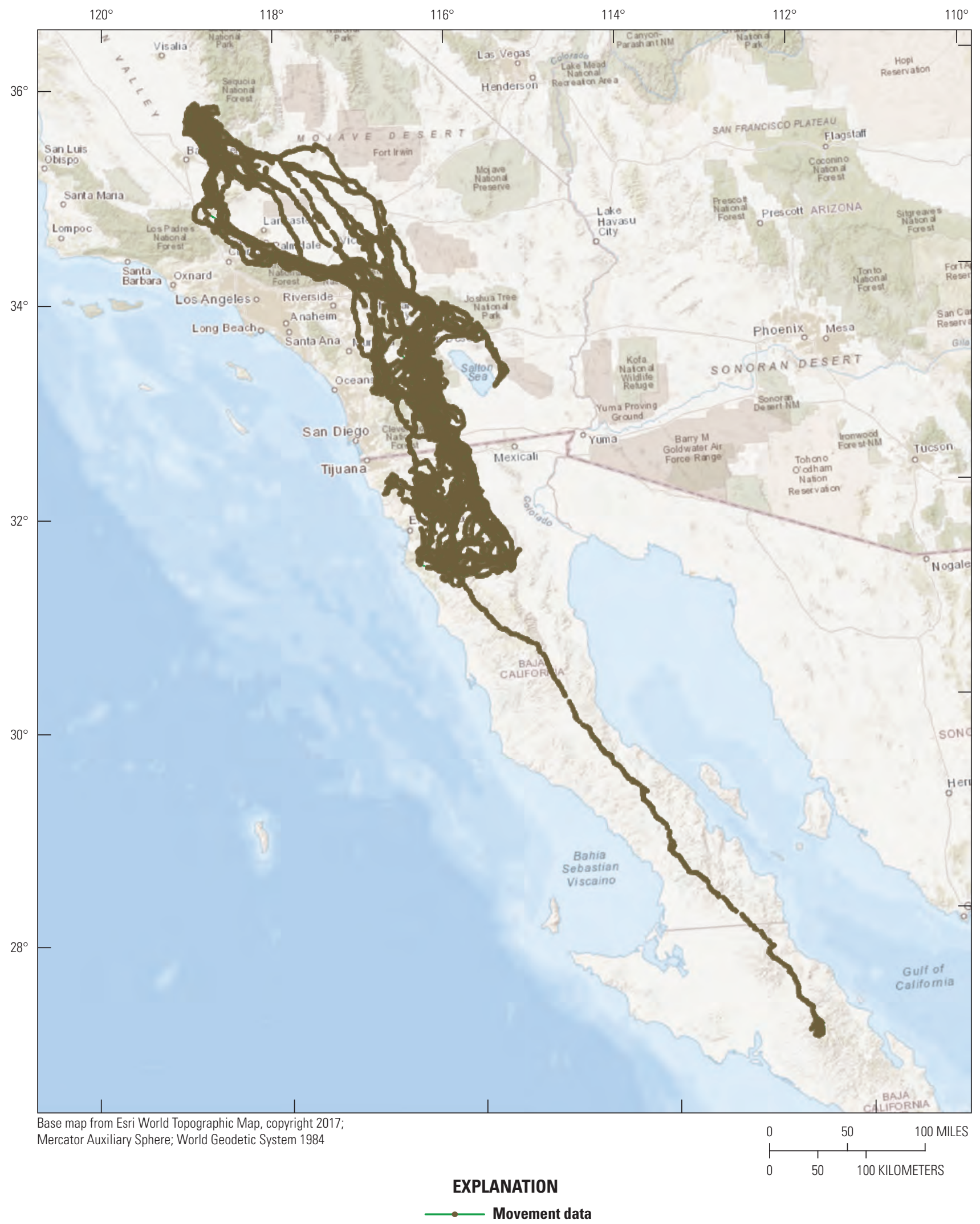

Figure 20. Location data for eagle GOEA-SD-F028 captured at Pamo Valley, San Diego County, California, March 18, 2018. 


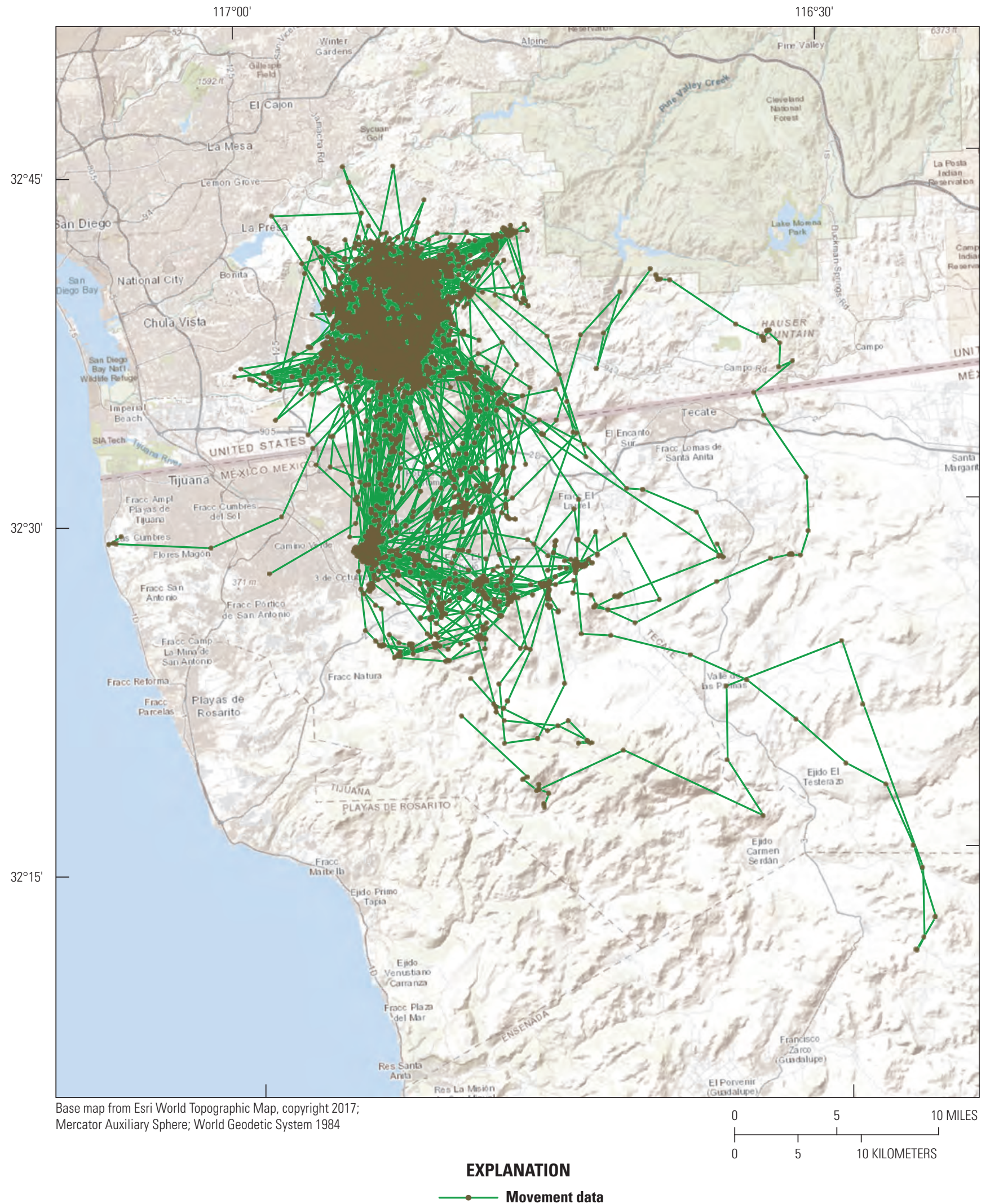

Figure 21. Location data for eagle GOEA-SD-M001 captured at Cedar Canyon, San Diego County, California, December 5, 2014. 


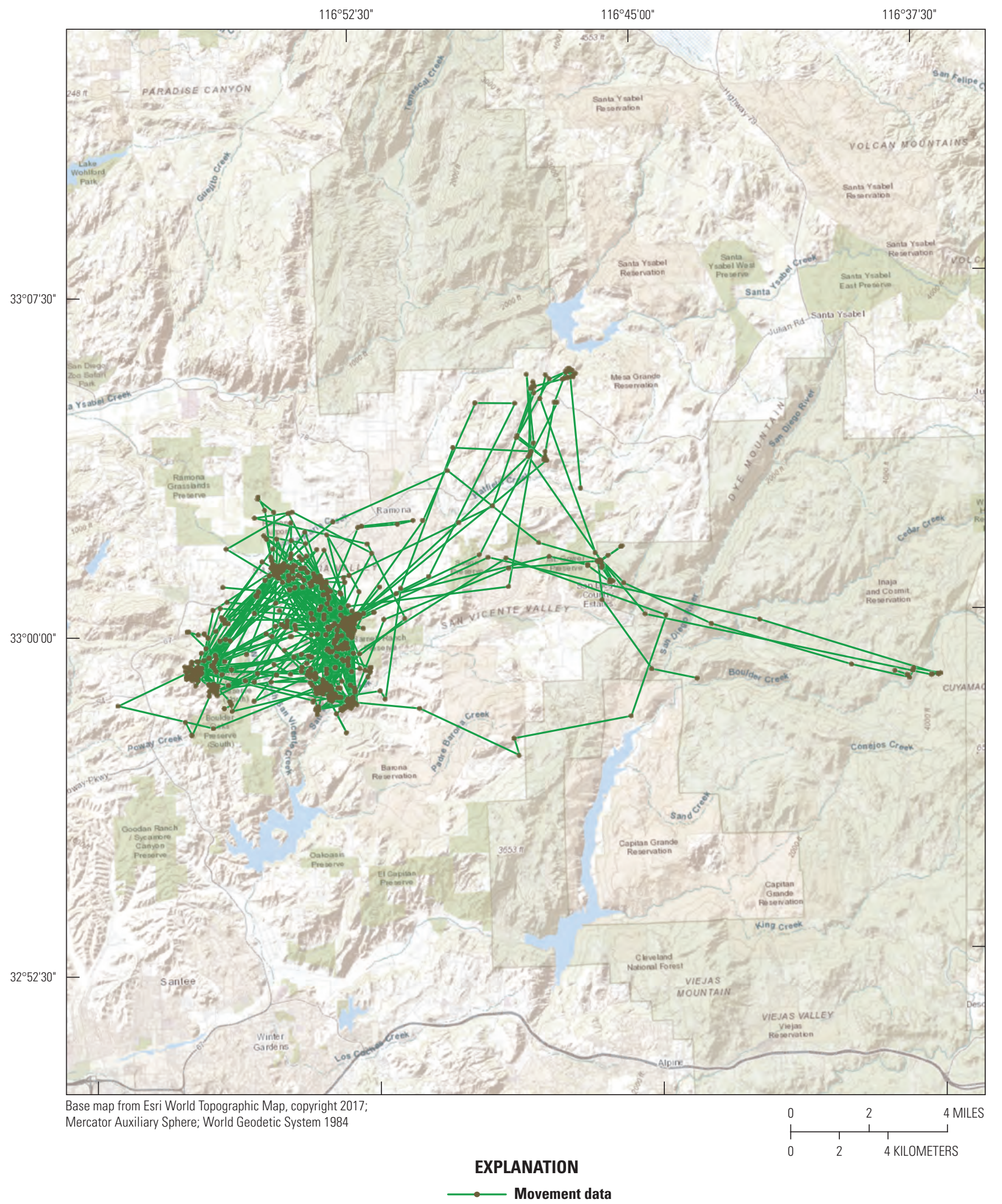

Figure 22. Location data for eagle GOEA-SD-M003 captured at Rancho Cañada, San Diego County, California, February 3, 2015. 


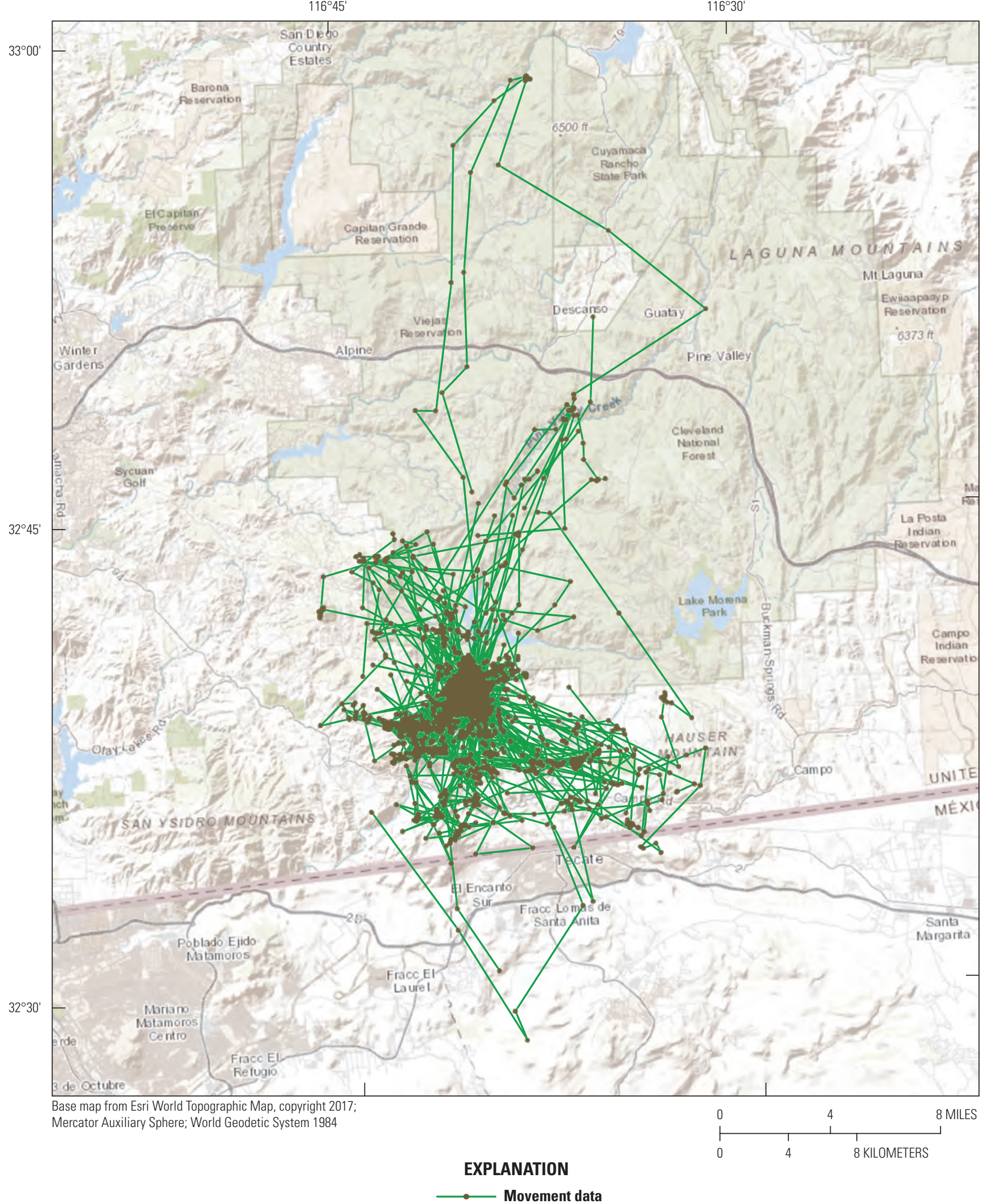

Figure 23. Location data for eagle GOEA-SD-M005 captured at Long Potrero, San Diego County, California, February 23, 2015. 


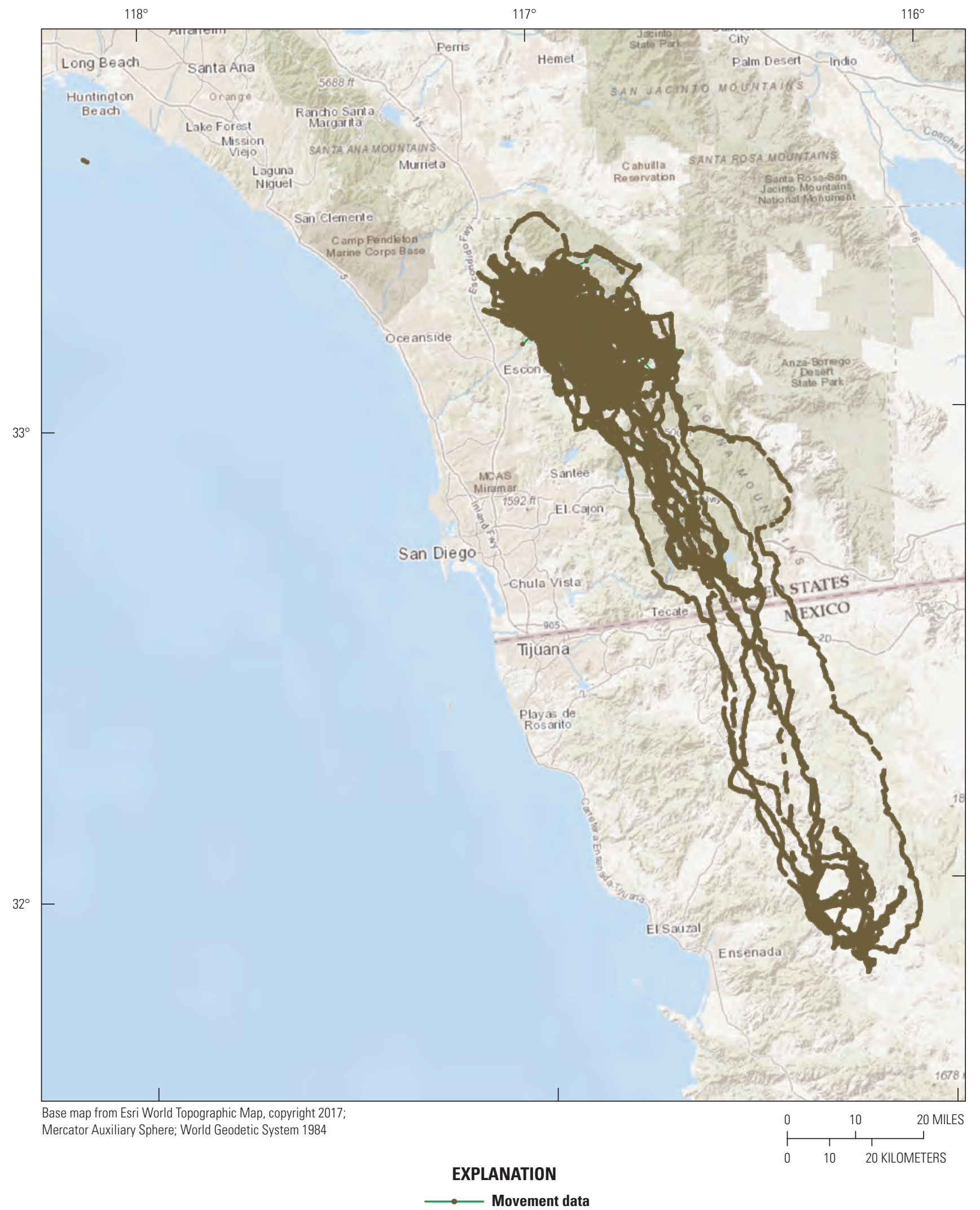

Figure 24. Location data for eagle GOEA-SD-M007 captured at Long Valley, San Diego County, California, December 9, 2015. 


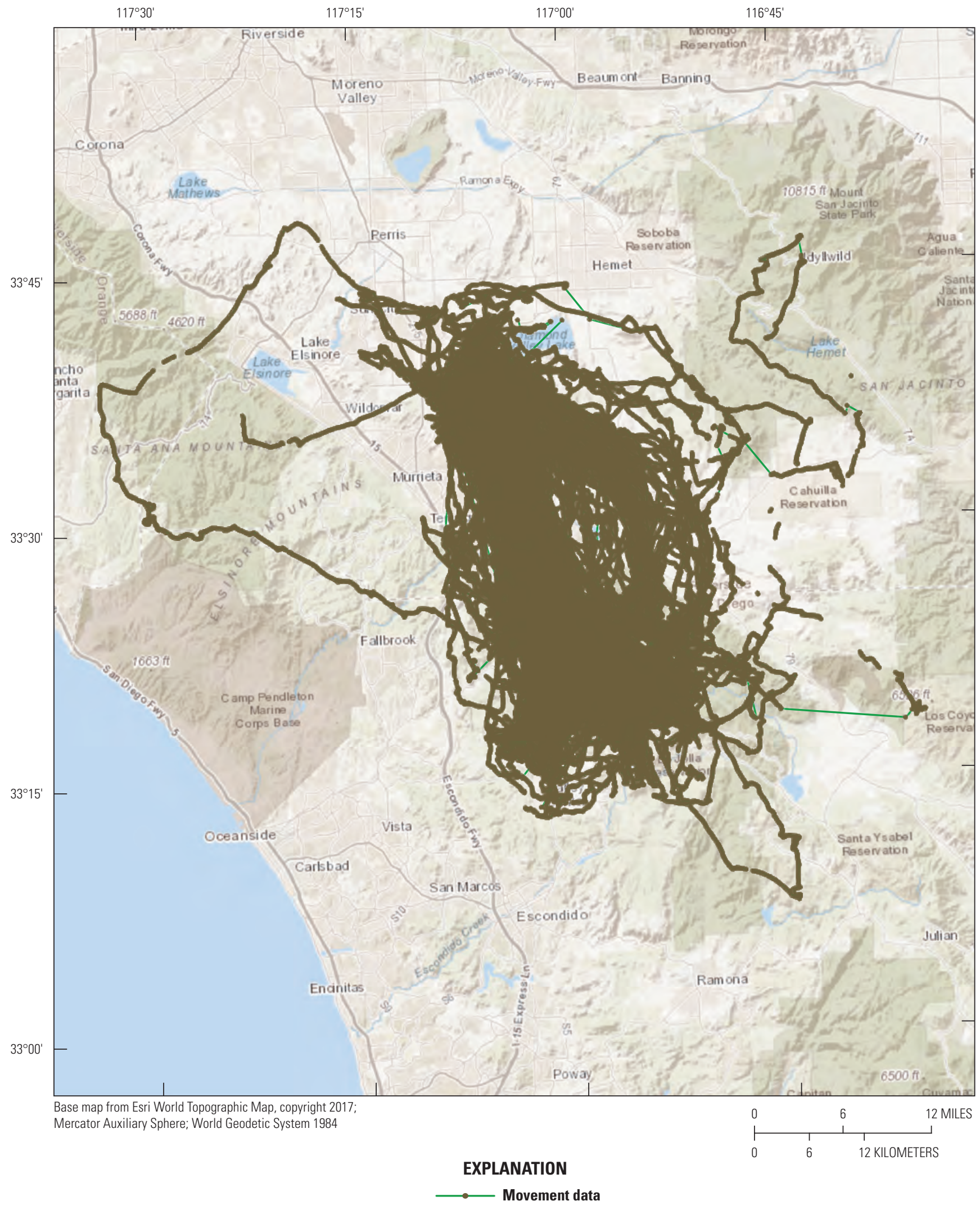

Figure 25. Location data for eagle GOEA-SD-M013 captured at Boucher Hill, San Diego County, California, November 20, 2016. 


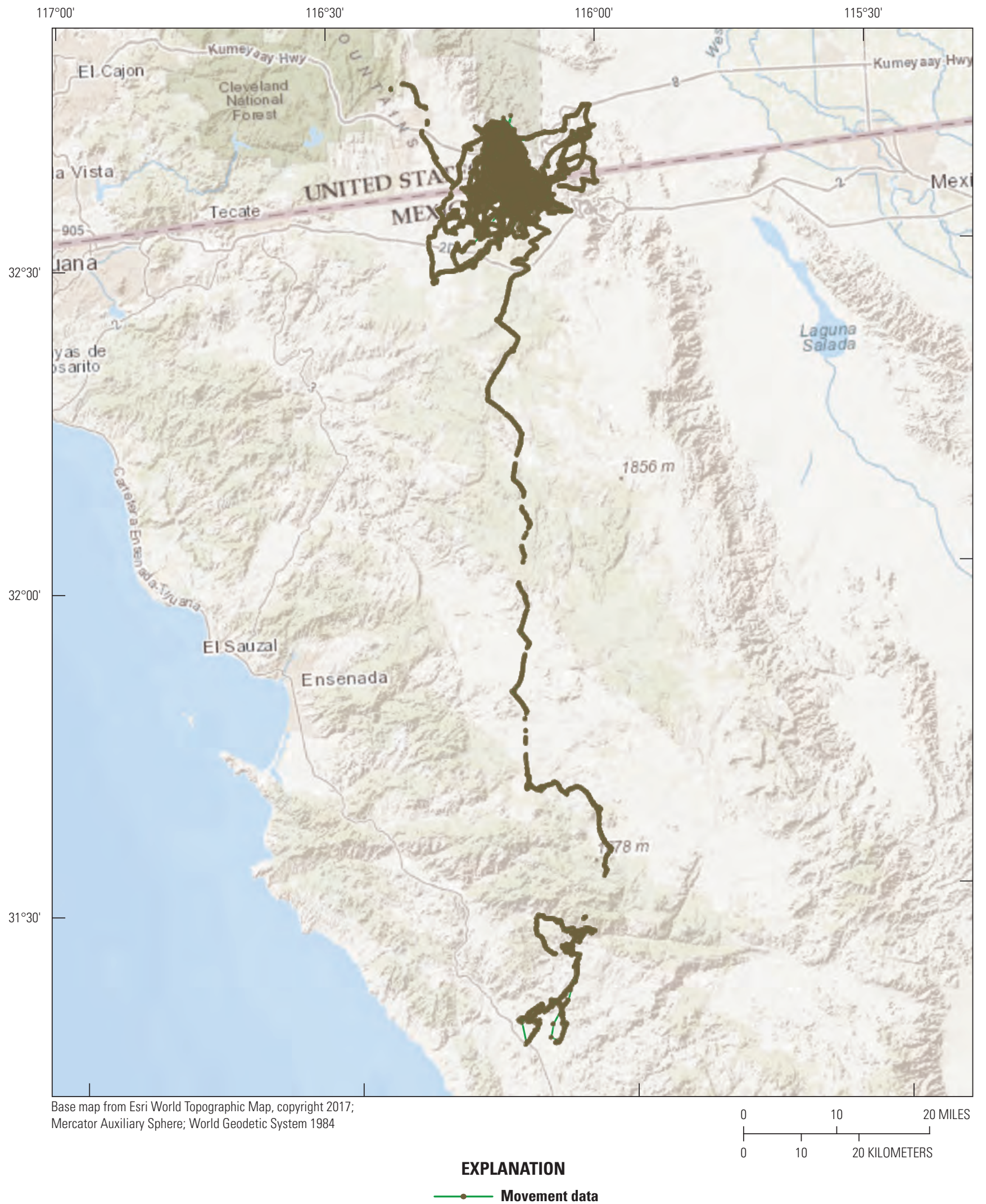

Figure 26. Location data for eagle GOEA-SD-M015 captured at Table Mountain, San Diego County, California, January 28, 2017. 


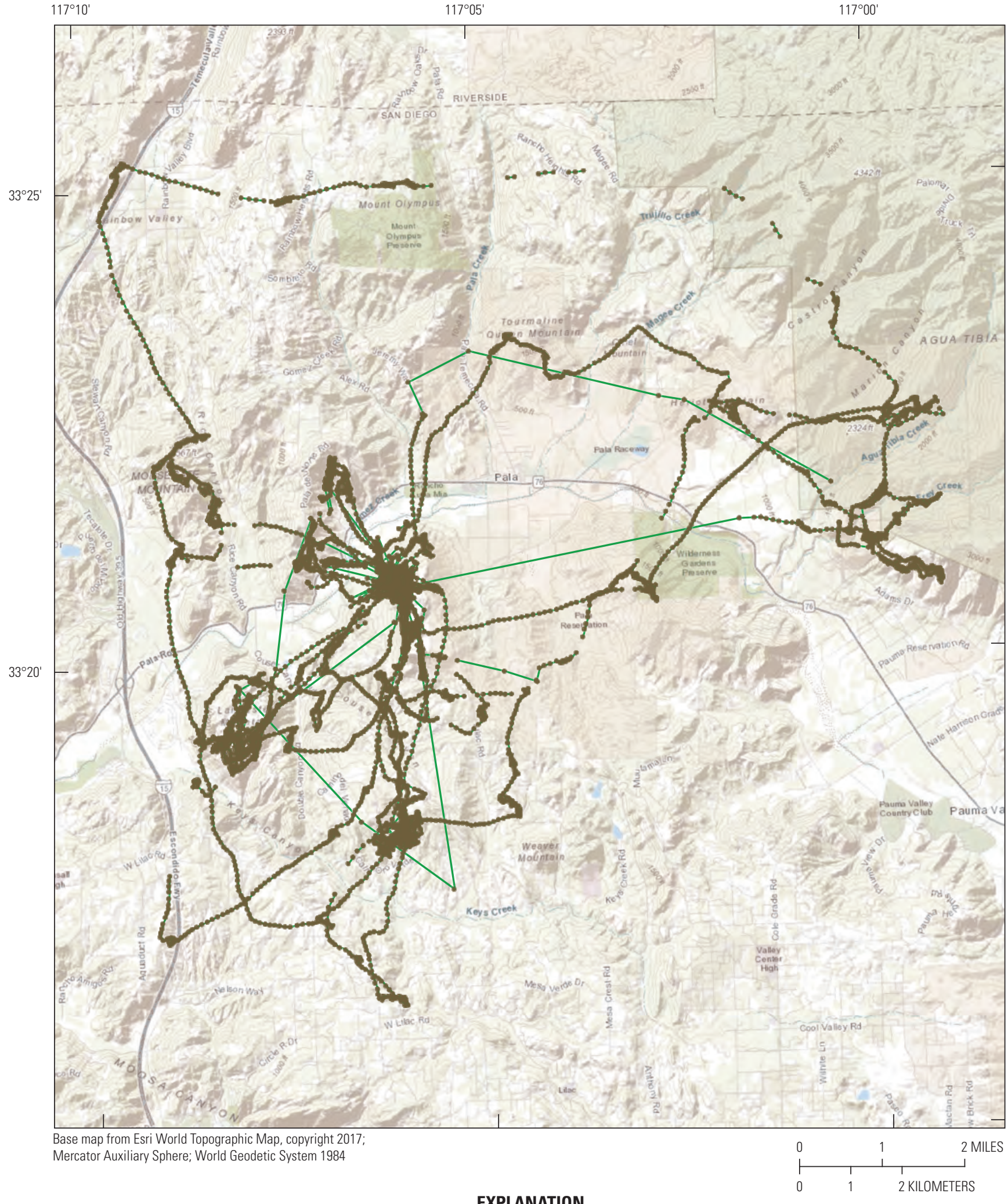

EXPLANATION

Movement data

Figure 27. Location data for eagle GOEA-SD-M019 captured at Gregory Mountain, San Diego County, California, January 30, 2018. 


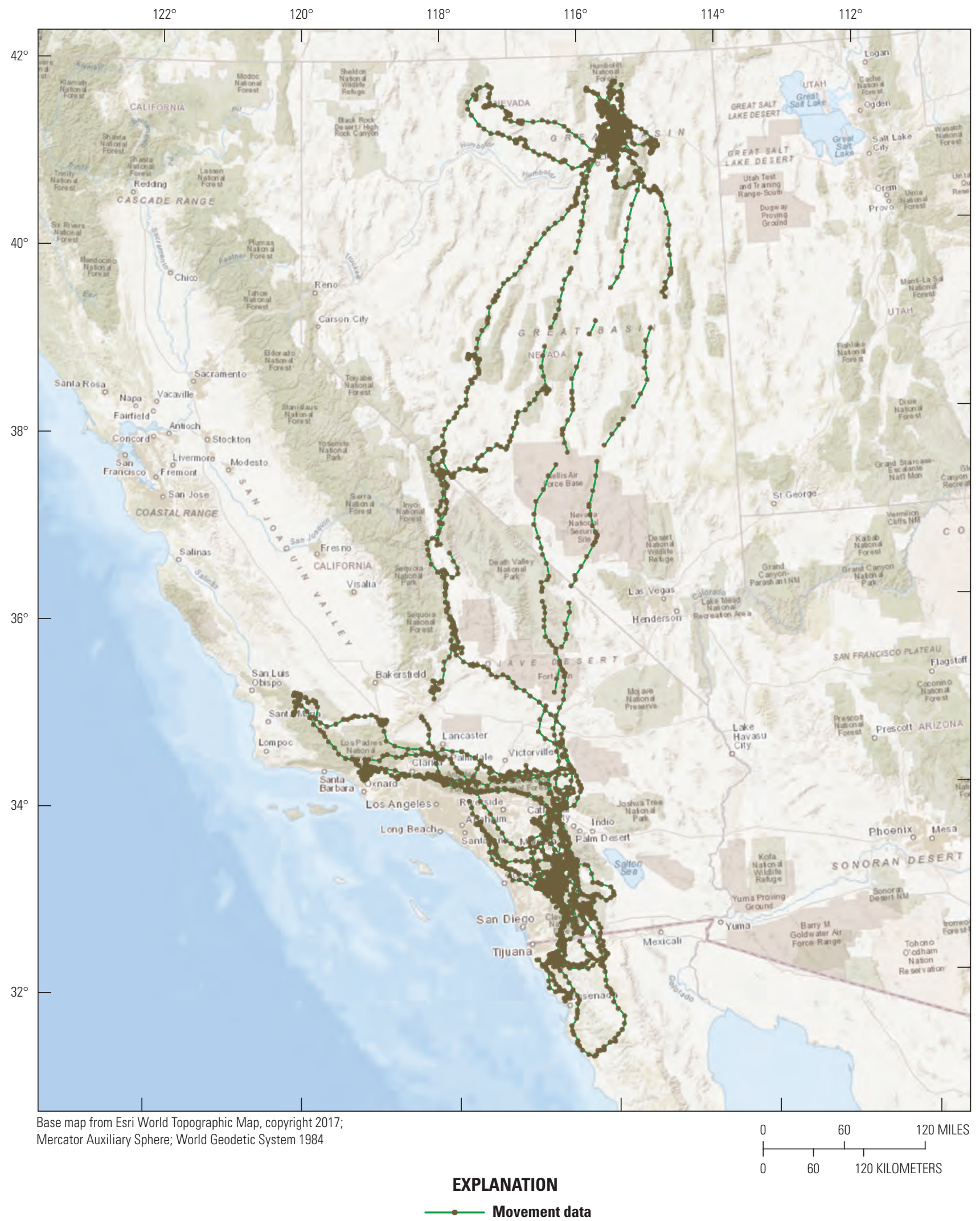

Figure 28. Location data for eagle GOEA-SD-M020 captured at Pamo Valley, San Diego County, California, January 31, 2018. 


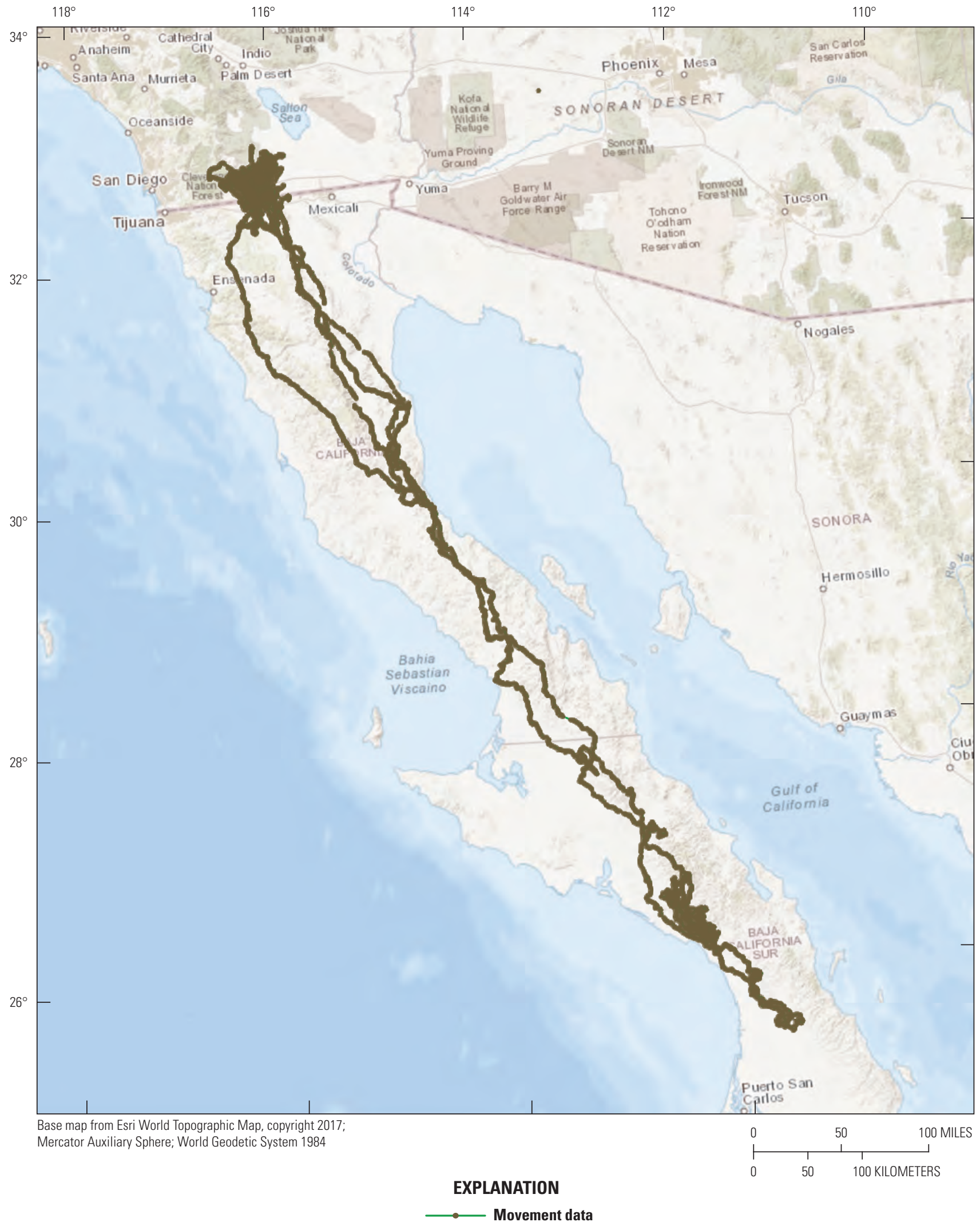

Figure 29. Location data for eagle GOEA-SD-M021 captured at McCain Valley, San Diego County, California, February 23, 2018. 


\section{References Cited}

Bloom, P.H., and Clark, W.S., 2001, Molt and sequence of plumages of golden eagles, and a technique for in-hand ageing: North American Bird Bander, v. 26, no. 3, p. $97-116$.

Braham, M.E., Miller, T.A., Duerr, A.E., Lanzone, M., Fesnock, A., Lapre, L., Driscoll, D., and Katzner, T.E., 2015, Home in the heat-Dramatic seasonal variation in home range of desert golden eagles informs management for renewable energy development: Biological Conservation, v. 186, p. 225-232, https://doi.org/10.1016/j.biocon.2015.03.020.

Dunstan, T.C., 1972, Radio-tagging Falconiform and Strigiform birds: Raptor Research, v. 6, no. 3, p. 93-102.

Harlow, D.L., and Bloom, P.H., 1989, Buteos and the golden eagle: Proceedings of the Western Raptor Management Symposium and Workshop, October 26-28, 1987, Boise, Idaho, National Wildlife Federation Scientific and Technical Series 12, p. 102-110.

Kenward, R.E., 1985, Raptor radio-tracking and telemetry: International Centre for Birds of Prey, Technical Publication 5, p. 409-420.
Lanzone, M.J., Miller, T.A., Turk, P., Brandes, D., Halverson, C., Maisonneuve, C., Tremblay, J.A., Cooper, J., O'Malley, K., Brooks, R.P., and Katzner, T.E., 2012, Flight responses by a migratory soaring raptor to changing meteorological conditions: Biology Letters, v. 8, no. 5, p. 710-713, https://doi.org/10.1098/rsbl.2012.0359.

Poessel, S.A., Bloom, P.H., Braham, M.A., and Katzner, T.E., 2016, Age- and season-specific variation in local and long-distance movement behavior of golden eagles: European Journal of Wildlife Research, v. 62, no. 4, p. 377-393, https://doi.org/10.1007/s10344-016-1010-4.

Scott, T.A., 1985, Human impacts on the golden eagle population of San Diego County: San Diego State University, San Diego, California, M.S. thesis.

Tracey, J.A., Madden, M.C., Sebes, J.B., Bloom, P.H., Katzner, T.E., and Fisher, R.N., 2016, Biotelemetry data for golden eagles (Aquila chrysaetos) captured in coastal southern California, November 2014-February 2016: U.S. Geological Survey Data Series 994, 32 p., https://doi.org/10.3133/ds994.

Tracey, J.A., Madden, M.C., Sebes, J.B., Bloom, P.H., Katzner, T.E., and Fisher, R.N., 2017, Biotelemetry data for golden eagles (Aquila chrysaetos) captured in coastal southern California, February 2016-February 2017: U.S. Geological Survey Data Series 1051, 35 p., https://doi.org/10.3133/ds1051. 
For more information concerning the research in this report, contact the Director, Western Ecological Research Center

U.S. Geological Survey

3020 State University Drive East

Sacramento, California 95819

https://www.usgs.gov/centers/werc

Publishing support provided by the U.S. Geological Survey Science Publishing Network, Sacramento Publishing Service Center 


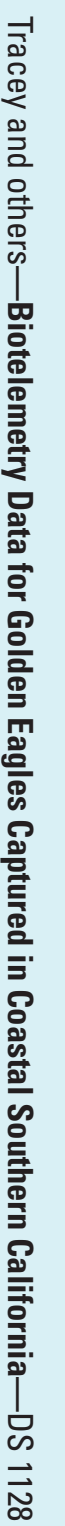

